\title{
INNOVATION IN THE U.S. GOVERNMENT
}

Joshua R. Bruce

John M. de Figueiredo

Working Paper 27181

http://www.nber.org/papers/w27181

\author{
NATIONAL BUREAU OF ECONOMIC RESEARCH \\ 1050 Massachusetts Avenue \\ Cambridge, MA 02138 \\ May 2020
}

We wish to thank Michael Andrews, Pierre Azoulay, Ronnie Chatterji, Shane Greenstein, Arti Rai, Scott Stern, Manuel Trajtenberg, and participants at the National Bureau of Economic Research Conference on the Role of Innovation and Entrepreneurship in Economic Growth for very helpful comments. The views expressed herein are those of the authors and do not necessarily reflect the views of the National Bureau of Economic Research.

NBER working papers are circulated for discussion and comment purposes. They have not been peer-reviewed or been subject to the review by the NBER Board of Directors that accompanies official NBER publications.

(C) 2020 by Joshua R. Bruce and John M. de Figueiredo. All rights reserved. Short sections of text, not to exceed two paragraphs, may be quoted without explicit permission provided that full credit, including $\odot$ notice, is given to the source. 
Innovation in the U.S. Government

Joshua R. Bruce and John M. de Figueiredo

NBER Working Paper No. 27181

May 2020

JEL No. H41,H54,K0,O31,O34

\begin{abstract}
$\underline{\text { ABSTRACT }}$
This paper examines the U.S. government's intramural research and development efforts over a 40-year period, drawing together multiple human capital, government spending, and patent datasets. The U.S. Federal Government innovates along four dimensions: technological, organizational, regulatory, and policy. After discussing these dimensions, the paper focuses on the inputs to and outputs of government intramural technological innovation. We measure innovative effort and results by accounting for the government scientists and dollars committed to $\mathrm{R} \& \mathrm{D}$ and patents created with government involvement. Overall, we show that intramural innovations, measured by government-assigned patents, are slightly more original and general, but less cited, than patents awarded to private-sector companies and extramural organizations patenting in the same technology classes. The majority of the 200,000 federal government scientists work at the Department of Defense, the Department of Energy, and NASA, and are largely in physical science and engineering occupations; the scientific expertise of other agencies is heavily weighted toward mathematics, social sciences, and data analytics. As these latter disciplines' innovative outputs are less readily catalogued with patents, measuring total government innovative output with government-assigned patents is likely to over-emphasize innovations in engineering and physical sciences while under-reporting intramural innovations in other disciplines. We discuss the implications of our findings for both public- and private-sector innovation efforts and pose questions for future research.
\end{abstract}

Joshua R. Bruce

4019 Business Instructional Facility

515 East Gregory Drive

Gies College of Business

University of Illinois at Urbana-Champaign

Champaign, IL 61820

joshb@illinois.edu

John M. de Figueiredo

The Law School and Fuqua School

Duke University

210 Science Drive, Box 90360

Durham, NC 27708

and NBER

jdefig@duke.edu 


\section{INNOVATION IN GOVERNMENT}

\section{INTRODUCTION}

In recent years, the U.S. federal government has spent over $\$ 120$ billion annually on research and development (R\&D). ${ }^{1}$ In addition, each OECD country spends the equivalent of billions of dollars every year to support technological infrastructure and advancement to further science and research. The literature on governments' contributions to the worldwide innovation ecosystem has focused on two areas: first, the role of government policy, such as intellectual property rules, tax credits, an infrastructure investments, to support private-sector innovation (e.g., Bloom, Van Reenen, and Williams 2019); and second, the role of government funds targeted to the private and non-profit sectors to enhance the direction, productivity, and efficiency of R\&D (e.g., Azoulay et al. 2019).

While both of these literatures are important to understanding the government's role in innovation, there has been comparatively little academic work examining the direction and effectiveness of government research itself. In fiscal year (FY) 2018, the U.S. federal government spent over $\$ 36$ billion on "intramural" $\mathrm{R} \& \mathrm{D}$ - that is, the innovation that the government funds and conducts itself — more than any individual company in the United States. ${ }^{2}$ In recent years, the federal government has employed approximately 200,000 scientists, just under half of whom engage in R\&D. Federal civil service scientists prolifically invent, innovate, patent, and publish. Yet, despite the number of personnel and the size of their research budgets,

\footnotetext{
${ }^{1}$ For an historical overview of federal R\&D spending levels, see the Congressional Research Service's "U.S. Research and Development Funding and Performance: Fact Sheet (Updated January 24, 2020)," available at: https://crsreports.congress.gov/product/pdf/R/R44307 (last accessed March 13, 2020).

${ }^{2}$ As a point of comparison, Amazon, the top R\&D spending company in the U.S., spent $\$ 22.6$ billion on R\&D in 2017; Alphabet/Google, the next-largest spender, allocated $\$ 16.6$ billion. See: https://www.vox.com/2018/4/9/17204004/amazon-research-development-rd (last accessed March 13, 2020).
} 
there is almost no systematic or comprehensive scholarship on the U.S. governments' intramural $R \& D$ efforts.

Our paper begins addressing this issue with a look into government innovation. We bring together a variety of datasets to provide an initial comprehensive picture of innovation in government. Some of these datasets, such as those on funding from the National Science Foundation (NSF), are widely available. Others, such as a dataset on U.S. government scientists and R\&D effort, have rarely been employed and never used in this capacity. Additional datasets, such as those linking U.S. government scientists to patents, have been available but have not been mapped comprehensively in the innovation literature. In this paper we bring these and other data together at an aggregate level to understand the inputs and outputs to government intramural innovation. The focus in this paper is on the U.S. federal government, but the approaches here are translatable to any government entity for which data is available.

This paper seeks to make four contributions. First, we provide a broad analysis of government intramural innovative inputs and outputs and, we believe, the first comparative analysis of intramural and extramural research efforts. In this capacity, we intend to provide a set of facts and regularities about government innovation. Second, we argue that much of government innovation, broadly defined, is difficult to measure. Innovation has many dimensions and much of the economics literature is focused on technological innovation. By constraining analyses to government technological innovation, researchers will miss much of the innovation that occurs in government. Third, even if we limit our analysis to technological innovation, traditional output measures of technological innovation will be heavily weighted toward agencies such as the Department of Defense, the National Aeronautics and Space Administration, and the Department of Energy. This is because the nature of innovation in these 
agencies will be engineering and physical science-oriented, where innovative outputs are somewhat easier to catalogue with patents. However, innovations in agencies which rely on mathematics, social science, and data analytics, for example, will often be missed by this measure. Overall, using traditional measures of patents as measure of innovative output, while informative, will be biased by the nature and variety of innovations which occur in government. Finally, the data shows that while the amount of government funding for R\&D has increased substantially over the past few decades, the number of government scientists has not. The government has shifted away from intramural research and toward a more extramural science orientation. In making this shift, the government may increase the diversity and efficiency of innovation but risks not developing the sufficient internal innovative capability to manage, direct, and develop science and research. We further discuss potential implications of this trend in the conclusion.

The paper proceeds as follows. In the next section, we provide a very brief overview of the U.S. federal government. In Section III, we develop a classification system for different types of government innovation. Section IV discusses inputs into government intramural innovation, with a focus on funding and manpower. Section $\mathrm{V}$ analyzes the outputs from intramural innovation, with a discussion of patents and other measures. In Section VI we briefly outline state government contributions to intramural R\&D. We conclude in Section VII with a brief discussion of implications and future research.

\section{OVERVIEW OF THE U.S. FEDERAL GOVERNMENT}

We begin with an overview of the federal government focusing on money (budget/appropriations) and manpower (human capital) as underlying indicators of government 
innovative input and capabilities. In fiscal year 2020, total U.S. federal government budgeted expenditures are estimated to total $\$ 4.6$ trillion dollars. ${ }^{3}$ Approximately $\$ 2.1$ trillion dollars of the budget is allocated to Social Security, Medicare, and interest on the debt. Approximately $\$ 1.5$ trillion dollars is spent on Medicaid, national defense, and other mandatory programs. Approximately $\$ 1$ trillion dollars remains for every other function of the government, from land management to foreign relations to agricultural research.

The U.S. federal government employs approximately 4.3 million full-time equivalent (FTE) workers in 2020. During 1998-2018, U.S. federal employees represented an average of $3.7 \%$ of the U.S. FTE workforce. ${ }^{4}$ As of 2020, about half of these employees are in the uniformed military (1.4 million) and the Post Office $(585,000)$, while the other half are civilians employed in executive branch agencies. ${ }^{5}$ In the rest of this paper, when referring to government personnel, we focus on full-time, non-seasonal executive branch civil servants.

Approximately $70 \%$ of these federal employees are on the General Schedule (GS) pay plan. This plan has 15 major levels, called "grades," with each movement upward in grade being a promotion in the government. ${ }^{6}$ Grade level is a convenient summary statistic for the skill level, education, and expertise of civil servants. ${ }^{7}$ Figure 1 shows the distribution of federal employees

\footnotetext{
${ }^{3}$ Congressional Budget Office (CBO) projection for FY2020, as of January 28, 2020. See: https://www.cbo.gov/topics/budget. If this spending were entirely production, it would represent around a fifth of the U.S. economy. However, the budget includes substantial transfers. This estimate was created before the COVID19 pandemic was recognized as a major health threat in the United States, which dramatically altered federal spending at the time this manuscript was being prepared.

${ }^{4}$ See the Bureau of Economic Analysis (BEA) National Accounts (NIPA), "Table 6.4B. Full-Time and Part-Time Employees by Industry" (last accessed February 28, 2020).

${ }^{5}$ There are roughly 75,000 FTE individuals employed in the legislative and judicial branches. For more, see the Congressional Research Service's "Federal Workforce Statistics Sources," updated Oct. 24, 2019: https://fas.org/sgp/crs/misc/R43590.pdf

${ }^{6}$ Each grade also has 10 steps. One convenient way to think about grades is as promotions; steps are pay increases for tenure and experience within a job.

${ }^{7}$ The starting grade for someone with 4-year college degree, for example, is grade 5; a master's degree is about grade 9; a PhD is grade 12. For more on the GS system, see the Office of Personnel Management's overview at https://www.opm.gov/policy-data-oversight/pay-leave/pay-systems/general-schedule/
} 
by grade in 1988 and in 2011 along with the median grade in these two fiscal years (Bolton and de Figueiredo 2016). The figure shows a shift from a bimodal distribution of grades of federal workers in 1988 to a more unimodal distribution of workers by 2011. More importantly, the average and median grade increased markedly over that 24 -year period following a substantial upskilling in the federal workforce. Figure 2 shows where this upskilling has taken place in the federal workforce by looking at the number of civil servants employed in five occupational categories over time (Bolton and de Figueiredo 2016). Figure 2 illustrates the drastic decline in the share of clerical workers in the government (from $24 \%$ to $7 \%$ ), commensurate with a significant increase in the proportion of more highly skilled "administrators" (29\% to $48 \%)$.

The literature in public administration has identified (at least) two causes of this upskilling in the workforce. The first is the rise of computers and automation which has allowed the federal government to remove the large clerical and typing pools that were essential to the operation of the government in the 1960s and 1970s (Rein 2014). Second, there has been a massive increase in the amount of outsourcing by the government, which has increased the need for more highly skilled procurement specialists, contract managers, accountants, and auditors (Light 2017). This upskilling and outsourcing of the federal workforce has translated into a fourfold increase in the number of budget dollars per employee over this 24-year period (Bolton and de Figueiredo 2016).

\section{CLASSIFICATION OF GOVERNMENT INNOVATIONS}

The public administration literature has considered a variety of approaches to classifying innovation (e.g., Arundel, Bloch, and Ferguson 2019; Chen, Walker, and Sawhney 2019; Hartley 2005; Vries, Bekkers, and Tummers 2016). Based on these approaches, we developed a 4category classification system that we believe describes most innovation carried out by federal 
employees and the federal infrastructure. While there is some overlap among these categories, together they describe much of the innovation carried out by the federal government.

The first category of government innovation is technological innovation. These innovations contain technically new and novel inventions and improvements that are consistent with the broader economics literature on technical change. Examples of government innovations in this category include diverse innovations such as hybrid vehicle control methods, inhibitors of integrase production to combat HIV, and snake repellant identification methods.

A second type of government innovation is organizational innovation. These are innovations which advance the way the government operates and is "organized," often resulting in greater administrative efficiency. Examples of organizational government innovations include the elimination of typing pools and introduction of computers, the implementation of oral proposals for some types of government procurement, novel approaches to managing civil service employees, and the crowdsourcing of citizen science.

A third type of government innovation is regulatory innovation. Unlike the private sector, the federal government's responsibilities include defining and administering the laws of the country through a regulatory apparatus. Regulatory innovations include the process of making rules and regulations, enforcing those regulations, and adjudicating these regulations. The government is continually evolving the rule-making process, within the rubric of the Administrative Procedures Act of 1946, through such recent innovations as negotiated rulemaking, electronic rulemaking (e-rulemaking), reformation of the drug approval process, and fast-track product recalls.

The fourth type of government innovation is also not found in the private sector: policy innovations. These innovations encompass the new types of regulatory policies and frameworks 
implemented by the administrative state to achieve desired social welfare and policy objectives. These are the actual policies and regulations themselves that the government has never implemented before, rather than mechanisms of regulatory process. Examples of policy innovations include the cap and trade program to combat air pollution and spectrum auctions to allocate broadcast rights over electromagnetic wave ranges. These policy innovations are not policies implemented by the government to encourage innovation per se, but these policy innovations may lead to technological innovation in the economy (as a second order effect, in most cases).

Although the focus of the literature (and the remainder of this paper) is on technological innovation, these technological innovations represent only a fraction of all innovation that is conducted by the U.S. government. The Ash Center at the Harvard University Kennedy School of Government has been accepting nominations for its Innovation in American Government Awards since $1985 .{ }^{8}$ Over the past 35 years, they have received thousands of nominations for the awards, with the vast majority of nominations being in the organizational, regulatory, and policy innovation areas. Table 1 provides a list of the U.S. federal agencies and their programs that won this award from 1995-1999, illustrating the breadth of programs and government entities engaged in innovation, much of which would not be captured by traditional innovation measures.

One challenge in the statistical literature on government innovation is that there is no standardized or readily available measure of government innovation that applies across all areas of government or all types of innovation. Even within specific agencies, these types of innovations are hard to consistently measure across time. If we are to understand the full scope of innovation in the government, future research should aspire to develop measures that are

\footnotetext{
${ }^{8}$ Federal agencies have been able to apply for the awards since 1995. See: https://ash.harvard.edu/iag-history
} 
consistent across agencies and across time, and available in statistically useful ways, to capture the government's true innovative power. Technological innovation is only the tip of the iceberg. Unfortunately, we do not solve this problem in this paper. Instead, we examine the most readily measurable area of government innovation - technological innovation - about which relatively little is currently known outside the National Institutes of Health (e.g., Li, Azoulay, and Sampat 2017).

\section{INPUTS INTO GOVERNMENT TECHNOLOGICAL INNOVATION}

In this section, we focus on the two main inputs into technological innovation by the government: funding and human capital.

\section{A. FUNDING BY THE GOVERNMENT}

The U.S. federal government spent over $\$ 120$ billion on R\&D in FY2018. ${ }^{9}$ Figure 3a shows federal spending on R\&D for 51 years by major government agencies and demonstrates that the Department of Defense (DOD) has consumed roughly 50\% of the R\&D spending for most of the past half-century. After the DOD, the Department of Health and Human Services (HHS), which houses the National Institutes of Health (NIH) and the Center for Disease Control (CDC), the Department of Energy (DOE), which conducts a substantial amount of nuclear weapons and energy generation research, the National Aeronautics and Space Administration (NASA), and the National Science Foundation (NSF), in order, possess the next largest government R\&D budgets. Together, these six agencies comprise over $90 \%$ of federal R\&D dollars appropriated.

\footnotetext{
${ }^{9}$ A note on federal spending nomenclature: "outlays" represent actual money spent in fulfillment of R\&D, whereas "obligations" represent contracted R\&D effort backed by Congressional appropriations, which often includes money to be spent in future fiscal years, leading to different amounts depending on which term is being used.
} 
Agencies allocate these appropriated funds to researchers who then perform R\&D. Figure $3 b$ shows how the money was allocated by the type of entity performing the actual R\&D effort. In FY2018, 31\% (\$39.8 billion) was directed to private sector companies; 24\% ( $\$ 31.5$ billion) went to higher education and universities; $10 \%$ ( $\$ 12.5$ billion) went to the operation of federallyfunded research and development centers (FFRDCs), ${ }^{10}$ such as the Jet Propulsion Lab (managed by the California Institute of Technology) or Los Alamos National Lab (managed by the nonprofit and university consortium Triad National Security, LLC); and 28\% (\$36 billion) of federal R\&D obligations were allocated to "intramural" research - that is, R\&D conducted by federal government civil servant scientists and researchers. The remaining $7 \%$ of R\&D obligations $(\$ 9.7$ billion) were directed to other non-profit organizations, state and local governments, and international R\&D.

Academic research has spent a substantial amount of energy examining the allocation of government money to universities (Lanahan, Graddy-Reed, and Feldman 2016; Mansfield 1995), the private sector (Azoulay et al. 2019; Bruce, de Figueiredo, and Silverman 2019; Howell 2017), and the FFRDCs (Jaffe, Fogarty, and Banks 1998; Jaffe and Lerner 2001; Jaffe and Trajtenberg 1996). These papers have examined both the direct effects of federal funds on scientific effort, as well as the interconnections between federally supported R\&D and other sectors' outcomes. However, there have been comparatively few studies of intramural research focused on understanding the work and productivity of government scientists. Therefore, in the remainder of the paper, unless specifically noted, we examine only intramural science.

\footnotetext{
${ }^{10}$ FFRDCs may be managed by the federal government, universities, private-sector businesses, or other non-profit organizations. For the purposes of this paper, all funding directed to the operation of FFRDCs by non-governmental organizations (also known as GOCOs) has been combined into a single category; government-run FFRDC (also known as GOGOs) obligations are included in the "intramural" category by the NSF.
} 


\section{B. HUMAN CAPITAL OF THE GOVERNMENT}

A second key input into government innovation is the manpower the government dedicates to the task. We have obtained from the Office of Personnel Management (OPM) elements of the Central Personnel Data File (CPDF-EHRI) which contains information on every federal government civilian employee that does not work in a sensitive position or sensitive agency. A detailed personnel dataset spans 1988 to 2011; a less detailed dataset spans 1980 to 2014. All personnel data presented herein are drawn from one of these two datasets unless otherwise noted.

We begin by examining the number of individuals in 68 distinct scientific occupations, whom we call scientists. ${ }^{11}$ The number of scientists in the government rose from 155,000 in 1980 to just under 200,000 by 2014 . These scientists, as illustrated in Figure 4a, are distributed across agencies, with approximately half of the scientists in the DOD and the remaining government scientists being found, in order of prevalence, in the Department of Agriculture (USDA), HHS, NASA, the DOE. Other agencies such as the Department of Commerce (Commerce), the Department of Veterans Affairs (VA), the Environmental Protection Agency (EPA), the

\footnotetext{
${ }^{11}$ The 68 scientific occupations and their categorization in the federal government broadly represent academic scientific disciplines. The occupations included are: (life sciences) microbiology, pharmacology, ecology, zoology, physiology, entomology, toxicology, botany, plant pathology, plant physiology, horticulture, genetics, soil conservation, soil science, agronomy, fish biology, wildlife biology, animal science, general health science, veterinary medical science; (math and statistics) general math and statistics, actuarial science, operations research, mathematics, mathematical statistics, statistics; (engineering and computer science) computer science, general engineering, safety engineering, fire protection engineering, material engineering, architecture, civil engineering, environmental engineering, mechanical engineering, nuclear engineering, electrical engineering, computer engineering, electronics engineering, bioengineering and biomedical engineering, aerospace engineering, mining engineering, petroleum engineering, agricultural engineering, chemical engineering, industrial engineering; (physical sciences) general physical sciences, health physics, physics, geophysics, hydrology, chemistry, metallurgy, astronomy and space science, meteorology, geology, oceanography, cartography, geodesy; (social sciences) social science, economist, workforce research and analysis, geography, history, psychology, sociology, general anthropology, archeology.
} 
Department of Interior (DOI), and the Department of Transportation (DOT) also possess a notable number of scientists.

Figure $4 \mathrm{~b}$ shows the concentration and intensity of scientific effort in these government agencies by examining the percent of all agency employees in scientific occupations. Perhaps not surprisingly, NASA has consistently had the highest concentration of scientific personnel, followed by the EPA, NSF, DOE, USDA, and HHS. Many of these agencies' smaller total workforces belie the science intensity in the agencies.

Despite being employed in scientific occupations, not all scientists in the government are primarily engaged in research. OPM classifies each federal scientist in one of 19 different primary activity categories, known as a "functional classification." ${ }^{12}$ We focus on a subset of the functional classifications to identify two groups of scientists: R\&D-focused and R\&D-adjacent. ${ }^{13}$ We classify a scientist as being in an R\&D-focused position if their primary job is to do research, development, testing and evaluation, or data analysis. We classify scientists as being in an R\&Dadjacent position if the scientist engaged primarily in R\&D grant administration, scientific and technical information processing/dissemination, or the management of science.

Figure 5a illustrates the distribution of scientists in R\&D-focused and R\&D-adjacent positions over a 24-year period in major scientific agencies, from which several important patterns emerge. First, about 87,000 government scientists engage in R\&D-focused work in the latest years where data is available, while about 26,000 government scientists are engaged in

\footnotetext{
${ }^{12}$ For more, see Appendix 2: Functional Classification for Scientists and Engineers in OPM's Introduction to the Position Classification System, available at: https://www.opm.gov/policy-data-oversight/classificationqualifications/classifying-general-schedule-positions/positionclassificationintro.pdf (last accessed February 15, 2020).

${ }^{13}$ There is a third group of scientific personnel whose work is not clearly R\&D-related, though they are employed in scientific occupations (e.g., a civil engineer with a functional classification of "production," which is focused on building construction). These scientific personnel in non-R\&D positions are included in the total scientists employed by the federal government discussed earlier, but not included in this R\&D-specific discussion.
} 
R\&D-adjacent activities. The DOD again has the largest share of federal R\&D scientists; NASA, HHS, USDA, and DOE have substantial numbers of R\&D-focused scientists, as well. Figure $5 b$ examines the percent of scientists by R\&D area. ${ }^{14}$ While the DOD again features prominently, NASA and HHS have comparatively high levels of R\&D-focused scientists as well. Figure $4 b$ and $5 \mathrm{~b}$ together show about $40 \%$ of non-DOD scientists are engaged in R\&D, with the exception of NASA, where the number is closer to $85 \%$.

To gain traction on the distribution of government scientists across scientific fields, we categorized, in Figure 6, the percent of scientists in five broader areas based on OPM classifications. Around $75 \%$ of the scientists in the DOD work in engineering and another $10 \%$ are in physical sciences, such as chemistry and physics. NASA and Energy exhibit similar patterns of scientific personnel being concentrated in engineering and the physical sciences. In contrast, in non-DOD agencies approximately one quarter of scientists work in engineering and an additional $18 \%$ in the physical sciences. In the latest years of data, around 30\% of non-DOD scientists work in social sciences or math and statistics, and an additional $20 \%$ are in the life sciences. Figure 6 also illustrates the concentration of HHS and USDA scientists in the life sciences in conjunction with their health, medical, and agricultural R\&D missions, each possessing $56 \%$ and $68 \%$ of their scientific workforce in the life sciences, respectively.

We believe there are three takeaway messages from the analysis of federal scientific human capital. First, the nature of innovation being conducted at the DOD is likely very different from the innovation in the non-DOD agencies based on the composition of its human capital. Second, the DOD is heavily focused on engineering and physical sciences, fields which lend

\footnotetext{
${ }^{14}$ The decline in HHS R\&D-focused personnel is largely the result of a reclassification of a substantial number of scientists at the NIH between FY2001 and FY2002. This occurred because all scientists hired in the excepted service under Title 42 with pay plan AD were converted from the "Research" to the "Other" functional classification with the implementation of the newly acquired human resources EHRP information technology system.
} 
themselves to patenting. Based on the scientific expertise of personnel, non-DOD agencies will tend to innovate in the social sciences, math, statistics, and life sciences. The former three areas do not lend themselves to patenting and the final area may or may not lend itself to patenting depending upon the nature of the scientific innovation. Our third takeaway is, therefore, that using patents as a measure of innovation in government will tend to overstate the nature of innovations being pursued by the DOD and understate the nature of innovations being conducted by non-DOD agencies, and it will overstate the contribution of the DOD to government innovation (assuming these innovations can be patented without national security concerns) and understate the contribution of the non-DOD agencies to government innovation. These distortions are critical to recognize when analyzing available data for indicators of public-sector innovative success.

\section{OUTPUTS FOR TECHNOLOGICAL INNOVATION IN THE FEDERAL}

\section{GOVERNMENT}

The previous sections of this paper focus on the inputs - human and financial capital— to technological innovation in the government, which are the precursor to government scientific innovation. This section begins by exploring the outputs of technological innovation, beginning with an in-depth analysis of patents followed by a discussion of viable alternative output measures. Although patents are likely to be informative of government technological output, they are unlikely to be comprehensive or necessarily representative measures of the scope, variety and nature of innovations that occur in the government.

Our analysis of patents is based on U.S. Patent and Trademark Office (USPTO) patent data, which has been processed and made available by PatentsView.org, a collaborative project 
between USPTO, USDA, the American Institutes for Research, and others. ${ }^{15} \mathrm{We}$ augment these records with measures made available by the NBER Patent Data Project. ${ }^{16}$

\section{A. PATENTS}

Government involvement in patented innovations takes two primary forms. First, if government scientists create a new invention, the government generally becomes the patent assignee, thereby holding the right to use or license the patented innovation. Second, if the government funds a third party, such as a university, to conduct research leading to a patented innovation, the third party generally takes ownership of the invention and becomes the patent assignee while the government maintains an "interest" in the patent. That interest is usually comprised of a royalty-free license to the invention. All patents generated with government funding are required to report the government's involvement in an interest statement on U.S. patent applications. ${ }^{17}$

Figure 7 illustrates the number of U.S. patents in which the government is an assignee and in which the government has an interest. From 1975 to 2013, the number of governmentassigned patents remained relatively stable at about 1,500 patents per year. ${ }^{18}$ Despite the stability of the number of government-assigned patents, the number of government interest patents has increased nearly 12 -fold during this time period, from roughly 500 patents/year to almost 6,000 patents/year. There are many reasons for this substantial increase in government

\footnotetext{
${ }^{15}$ See: www.patentsview.org (last accessed February 29, 2020).

${ }^{16}$ See: https://sites.google.com/site/patentdataproject/Home (last accessed February 29, 2020).

${ }^{17}$ Researchers have found heterogeneity in inventors' disclosure of government interest in their inventions, which may result in an under-reporting of government support for innovation (Rai and Sampat 2012). Patents generated by CRADAs and other scientific procurement mechanisms, especially at the DOD, do not always include an explicit government interest statement or assignment.

${ }^{18}$ To put this number in a comparative perspective, the time series profile of the number of government-assigned patents is comparable to the time series profile of the number of patents assigned to Texas Instruments Incorporated over a similar time period.
} 
interest patents (which are beyond the scope of this paper) including increased government extramural innovation funding, the Bayh Dole Act, career concerns for academic scientists, and numerous other factors (Azoulay et al. 2019; Berman 2008; Fleming et al. 2019; Hegde and Mowery 2008; Jaffe and Lerner 2001; Owen-Smith and Powell 2001).

Figures $8 \mathrm{a}$ and $8 \mathrm{~b}$ illustrate the total number of patents granted during 1975-2013 with either a federal government assignee or government interest statement tied to a federal agency, respectively. The DOD generates, by far, most of the government-assigned patents (Figure 8a), while HHS generates most of the government-interest patents (Figure 8b). These patterns comport with the human capital trends highlighted earlier, as government-assigned patents tend to be most focused on engineering and physical science technologies while government-interest patents are more heavily clustered in the life sciences.

Figure 9 shows the top five Cooperative Patent Classification (CPC) technological subsections for government-assigned and government-interest patents over nearly 40 years. ${ }^{19}$ In addition to the distribution across technologies, we see relative stability in the top CPC subsections for government-assigned patents and the rise of biological and medical-related patents in the government-interest patents.

An alternative way to measure the contribution of government intramural science to technology is to measure the government's patent share in various technological areas. Figure 10 shows the share of government-assigned patents relative to all patents from 1975 to 2013 for five

\footnotetext{
${ }^{19}$ The CPC is a classification scheme developed between the USPTO and European Patent Office in an effort to harmonize patent classes around the world. For more, see: https://www.uspto.gov/patents-applicationprocess/patent-search/classification-standards-and-development or https://www.cooperativepatentclassification.org/about (last accessed February 29, 2020). CPC subsections are the second level of specificity within the CPC hierarchy. For example, within the overarching CPC section of "A: Human Necessities" (Level 1), there is a subsection devoted to "A01: Agriculture; Forestry; Animal Husbandry; Hunting; Trapping; Fishing" (Level 2), within which there is a group for patents in "A01D: Harvesting; Mowing" (Level 3). We discuss patents at the second and third levels of the CPC hierarchy (i.e., subsections and groups, following the PatentsView.org labels).
} 
CPC groups (tertiary level). These five CPC groups have the highest average weighted percent of government patents out of all $671 \mathrm{CPC}$ patent groups. ${ }^{20}$ Figure 10 highlights the five patent groups where the government has the largest patent share: Manufacturing Explosives, Ammunition Fuses, Explosive Charges, Radio-Based Navigation, and Chemical/Physical Materials Analysis. This heavy patent share in national defense-related technologies is perhaps not surprising given the technological focus and magnitude of the DOD intramural R\&D effort on what is likely patentable technologies.

Having established the focus of government patenting, we now examine character and quality of the patents generated by the government. The results we present in the remainder of this paper subsection were conducted for each of the top five patent CPC subsections identified in Figure 9. Because the results are largely similar across all five of these subsections, we present the results only for the top government-assigned subsection, measuring and testing technologies, in Figure 11a-c. ${ }^{21}$

We begin with an analysis of patent novelty. In this paper, we employ two measures of novelty based on the work of Trajtenberg et al. (1997), which are made available by the NBER Patent Data Project. ${ }^{22}$ The first novelty measure we look at considers the originality of patents, which is based on the breadth of patents to which the focal patent cites backward. ${ }^{23}$ Figure 11a presents the results from 1980 to 2003 for patents in the Measuring and Testing technologies

\footnotetext{
${ }^{20}$ The weighted average used to determine which CPC groups have the highest concentration of government patents is calculated by multiplying the annual percent of patents in each group assigned to the federal government by the number of government patents in the group, averaged across all years.

${ }^{21}$ Results for the remaining CPC subsections are available from the authors.

${ }^{22}$ Researchers have also developed alternative measures of patent novelty (Balsmeier et al. 2018; Fleming and Sorenson 2004; Trajtenberg, Henderson, and Jaffe 1997). We use the Trajtenberg et al measures because of their scope and ready availability through 2003.

${ }^{23}$ originality $_{\text {patent }}=1-\sum_{1}^{C} c_{\text {cited }}^{2}$, where $c^{2}$ is the squared proportion of patents cited by the focal patent from a single patent class, summed across all classes cited, $C$. Originality is thus a backward-looking measure of novelty, encompassing the breadth of scientific areas the focal patent incorporates.
} 
subsection, comparing patents assigned to the federal government with those assigned to U.S. companies. It shows that both the government and corporate inventions are, on average, more original over time, but that over almost the entire time period, government-assigned patents are slightly more original than the corporate patents in Measuring and Testing.

As a second measure of novelty, we calculate Trajtenberg et al.'s (1997) measure of patent generality, which is based on the breadth of later patents citing the focal patent. ${ }^{24}$ Figure $11 \mathrm{~b}$ illustrates that both groups of patents are, on average, slightly more general over time, but again, that government-assigned patents are slightly more general than private company patents.

Finally, we examine the citations to Measuring and Testing patents in Figure 11c. Some authors have referred to patent citations as a measure of patent quality (Henderson, Jaffe, and Trajtenberg 2005; Trajtenberg 1990). Here, there is a noticeable difference between the two sets of patents. The government assigned patents are substantially less cited than the private company patents in these patent classes, and that pattern persists for the entire time series of the data. In summary, in the five patent classes we examined, we find that relative to private company patents, the government assigned patents are slightly more original, slightly more general, but substantially less cited.

We conduct a similar analysis comparing government interest patents with private company patents in the same five CPC subsections. These results show a similar pattern in terms of patent novelty: government interest patents are slightly more original and slightly more general than commercial patents without a government interest statement. However, unlike

\footnotetext{
${ }^{24}$ generality $_{\text {patent }}=1-\sum_{1}^{C} c_{\text {citing }}^{2}$, where $c^{2}$ is the squared proportion of patents citing the focal patent from a single patent class, summed across all classes citing, $C$. Generality is a forward-looking measure of novelty, illustrating the degree to which the focal patent is later drawn on by patents in numerous other classes.
} 
government assigned patents, government-interest-statements patents are not meaningfully less cited than private-sector patents in the same CPC subsections. ${ }^{25}$

While the examples in Figure 11 are illustrative of areas of heavy government technology focus, there is no a priori assumption that our findings would hold across all scientific areas. To address the question of how general the pattern of greater originality and generality coupled with lower average citations is, we collect all granted patents in the CPC groups for all years when the federal government has at least one patent in a group. We then use ordinary least squares (OLS) regression to estimate three models describing (1) patent originality, (2) patent generality, and (3) patent citations. Each model includes CPC group (third-level specificity) and patent-grantyear fixed effects to control for differences by area of science and period effects, as well as heteroskedasticity-robust standard errors. In addition to accounting for whether a patent is assigned to the federal government, patents are also categorized as University-assigned if the words "college," "university," "regents," or "fellows" appear in the patent assignee name. Table 2 presents the results of these three OLS models that are meant to be merely reduced-form descriptions of the data.

Table 2 confirms the patterns identified and discussed from Figure 11. Government patents, relative to patents assigned to other entities (excluding universities), are more novel as measured by both originality and generality. Furthermore, government-held patents are less cited that patents held by other assignee types. ${ }^{26}$ University patents are more original, general, and highly cited than commercial patents.

\footnotetext{
${ }^{25}$ These results are available from the authors.

${ }^{26}$ This result remains consistent when using a negative binomial regression model rather than OLS to estimate the number of citations received. The NBER data containing patent originality and generality measures are based on the USPTO patent class system, not the CPC scheme. Recreating the Trajtenberg et al. (1997) measures with CPC groups replicates the results in Table 2 .
} 
In sum, our analysis of patent novelty and impact suggests two distinct results. First, the government appears to be conducting more original and more general science than the private sector. However, the second pattern of lower citations suggests that other inventors are not building on the government's innovations to the same degree they build on private sector innovations, or alternatively, that the government is innovating in areas that receive less overall innovative attention.

\section{B. ALTERNATIVE MEASURES OF GOVERNMENT INNOVATION}

While patents provide a convenient method for examining a slice of technological innovation by the federal government, there are a host of other potential output metrics that could be explored in future research. In this subsection, we discuss these alternative measures.

The first is the use of academic publications by government scientists. For many innovative ideas and inventions, publications embody or precede the innovative contribution, whether it be a contribution to knowledge or a commercial application of an idea. Indeed, publications and citations thereto are already used in the innovation literature as a measure of output (Angrist et al. 2020; Murray and Stern 2007). With respect to government science, publications are likely to be more representative of innovative output relative to patents in many fields, such as economics, sociology, data analytics, mathematics, management, and parts of the life sciences. Indeed, using publications as a measure of government innovative output would likely increase the proportion of government innovation reported by agencies such as the USDA, Commerce, and the EPA, for example, and allow researchers to obtain a more representative picture of government technical output.

A second potential output measure for government innovation is prizes (Jones 2010; Jones and Weinberg 2011). Agencies within the U.S. government award prizes to government 
scientists and personnel for innovations that enhance efficiency in the governing process and that contribute to knowledge and invention. These prizes can be for individual or team effort. ${ }^{27}$ Although prizes cannot be awarded for every innovation, prize data has the advantage of incorporating potentially unobservable information (to the researcher) on the contemporaneous contribution of individuals to innovation in the federal government. While the prize data is not mapped to individual innovations, it is mapped to individual civil servants (Zhang and de Figueiredo 2018), which might also allow researchers to identify "superstar" government innovators and the complementarities and externalities they generate (Zucker and Darby 1996). Likewise, third party prizes, such as the Ash Center prizes for innovativeness in government, might be a vehicle for understanding the contribution of innovations to government efficiency and social welfare.

A third potential method for evaluating the success of government technological innovations is to consider innovations where the government is a lead user. There is a large literature on user-driven innovation (for a summary, see: Franke 2014). Lead users are those who adopt an innovation at the beginning of the innovation's lifecycle (von Hippel 1986). Those lead users that stand to capture substantial value from the innovation's success have a high incentive to pursue the innovation themselves (Morrison, Roberts, and von Hippel 2000; Morrison, Roberts, and Midgley 2004). One might rely on this literature to understand when intramural efforts of government innovation are likely to succeed. NASA's development of technologies from rocket propulsion to life-sustaining systems during the Mercury and Apollo programs in the 1960s and 1970s, the government's invention of tabular computing to compile the U.S. Census

\footnotetext{
${ }^{27}$ There are four types of relevant prizes: individual and group awards, as well as suggestion and invention awards. The former distinguish between individual and group efforts, while the latter distinguish between process improvements and scientific or patentable innovation accomplishments, respectively.
} 
in the 1940s and 1950s, and the DOD's and NSF's need to connect disparate computing power leading to the Internet, are just a handful of examples where the incentives and investments of the U.S. intramural R\&D efforts were enhanced because of government as the lead user (Hacker and Pierson 2016; Mazzucato 2013; Singer 2014).

\section{STATE \& LOCAL GOVERNMENT TECHNOLOGICAL INNOVATION}

Throughout this paper, we have focused on the federal government as the primary publicsector actor in U.S. government technological innovation. However, state-level governments also contribute to intramural R\&D efforts. Figure 12 illustrates state spending in the seven cumulatively highest-spending states over the decade leading up to 2018 (dim lines in the background represent the remaining states). New York state spent over $\$ 822$ million during this period, in 2018 constant dollars, followed by California ( $\$ 560$ million) and Florida ( $\$ 299$ million).

States also indirectly subsidize $R \& D$ through many mechanisms. One mechanism is funding the operation of public colleges and universities, which are heavily reliant on state appropriations for their operation. This source of funding declined precipitously after the Great Recession. Although it has been rising since its nadir in 2013, it still remains below pre-recession levels in most states. ${ }^{28} \mathrm{~A}$ second mechanism is through policies, subsidies, and regulations that attract extramural R\&D. These, and other mechanisms, are worthy of further analysis and research.

\footnotetext{
${ }^{28}$ In its 2018 higher education finance report, the State Higher Education Executive Officers Association compared multiple measures of state support for college and university operations, such as per-capita spending and allocations as a percent of state tax revenue. Across multiple measures, the vast majority of states all showed considerable reductions in higher education funding when comparing 2008 to 2016. Report available at: https://sheeo.org/wpcontent/uploads/2019/04/SHEEO_SHEF_FY18_Report-2.pdf
} 


\section{CONCLUSION}

The vast majority of the literature on governments' role in innovation focuses on either the allocation and productivity of government funds directed to third party research or on various government policies that will enhance private and non-profit sectors' innovative effort. This paper examines the nature of intramural government research - the inputs and outputs of government scientists and funding toward internal innovation. We believe this analysis of government intramural innovative inputs and outputs is one of the first comparative analyses of the intramural-to-extramural research efforts.

The paper develops a classification system of innovation in the government, identifying four major types of public-sector innovations: technological, organizational, regulatory, and policy. It is inherently difficult to measure government innovation because a substantial amount of such innovation occurs in the latter three categories. Therefore, studies that attempt to measure the full government innovative effort are likely to miss much of the non-technological innovation that occurs in the federal government. We believe that a more robust and comprehensive innovation measurement system is needed to capture the full innovative output of the federal government.

When constraining the analysis to only government technological innovation, we see that inputs (scientists and funding) are heavily weighted toward the DOD, NASA, and DOE. Not surprisingly, output-oriented measures of innovation, such as patents, are also heavily weighted toward these agencies because of the scientific disciplines from which they draw: engineering, the physical sciences, and some parts of the life sciences. Patents will tend to miss innovations in agencies which rely on data analytics, social science, mathematics, and other parts of life science. Thus, patents will give a biased view of the composition of technological innovation in 
the government. Despite this, the patents that are generated by government scientists are slightly more original, slightly more general, but much less cited than those of the private sector.

One strong trend in the data is that while the amount of government funding for R\&D has increased substantially over the past few decades, the number of government scientists has remained relatively stable. The government has shifted toward a more extramural science orientation. This may be a good policy if policymakers believe it stretches the innovativeness and diversity of ideas and inventions, creates more efficient discovery and commercialization, or supports a broader scientific infrastructure of the country. However, these advantages will be mitigated if excessively outsourcing science diminishes the capability of the government to conduct some necessary intramural research, to monitor extramural research, to overcome market failure in the private markets for research, or to develop a socially optimal scientific infrastructure.

Overall, this paper is only an initial look at the U.S. government's intramural science efforts. It is meant to provide an opening into new research in this field, which could more fully understood and better mapped. This work attempts to provide a base for future research to understand the role of government innovation and entrepreneurship in economic growth. 


\section{REFERENCES}

Angrist, Josh, Pierre Azoulay, Glenn Ellison, Ryan Hill, and Susan Feng Lu. 2020. "Inside Job or Deep Impact? Extramural Citations and the Influence of Economic Scholarship.” Journal of Economic Literature 58(1):3-52.

Arundel, Anthony, Carter Bloch, and Barry Ferguson. 2019. "Advancing Innovation in the Public Sector: Aligning Innovation Measurement with Policy Goals.” Research Policy 48(3):789-98.

Azoulay, Pierre, Joshua S. Graff Zivin, Danielle Li, and Bhaven N. Sampat. 2019. "Public R\&D Investments and Private-Sector Patenting: Evidence from NIH Funding Rules." The Review of Economic Studies 86(1):117-52.

Balsmeier, Benjamin, Mohamad Assaf, Tyler Chesebro, Gabe Fierro, Kevin Johnson, Scott Johnson, Guan-Cheng Li, Sonja Lück, Doug O’Reagan, Bill Yeh, Guangzheng Zang, and Lee Fleming. 2018. "Machine Learning and Natural Language Processing on the Patent Corpus: Data, Tools, and New Measures." Journal of Economics \& Management Strategy 27(3):535-53.

Berman, Elizabeth Popp. 2008. "Why Did Universities Start Patenting?: Institution-Building and the Road to the Bayh-Dole Act." Social Studies of Science 38(6):835-71.

Bloom, Nicholas, John Van Reenen, and Heidi Williams. 2019. "A Toolkit of Policies to Promote Innovation.” Journal of Economic Perspectives 33(3):163-84.

Bolton, Alexander, and John M. de Figueiredo. 2016. "Why Have Federal Wages Risen So Rapidly?"

Bruce, Joshua R., John M. de Figueiredo, and Brian S. Silverman. 2019. "Public Contracting for Private Innovation: Government Capabilities, Decision Rights, and Performance Outcomes.” Strategic Management Journal 40(4):533-55.

Chen, Jiyao, Richard M. Walker, and Mohanbir Sawhney. 2019. "Public Service Innovation: A Typology." Public Management Review 1-22.

Fleming, L., H. Greene, G. Li, M. Marx, and D. Yao. 2019. "Government-Funded Research Increasingly Fuels Innovation.” Science 364(6446):1139-41.

Fleming, Lee, and Olav Sorenson. 2004. "Science as a Map in Technological Search." Strategic Management Journal 25(8/9):909-28.

Franke, Nikolaus. 2014. "User-Driven Innovation." in The Oxford Handbook of Innovation Management, edited by M. Dodgson, D. M. Gann, and N. Phillips. Oxford: Oxford University Press.

Hacker, Jacob S., and Paul Pierson. 2016. American Amnesia. New York: Simon \& Schuster. 
Hartley, Jean. 2005. "Innovation in Governance and Public Services: Past and Present." Public Money \& Management 25(1):27-34.

Hegde, Deepak, and David C. Mowery. 2008. "Politics and Funding in the U.S. Public Biomedical R\&D System.” Science 322(5909):1797-98.

Henderson, Rebecca, Adam Jaffe, and Manuel Trajtenberg. 2005. "Patent Citations and the Geography of Knowledge Spillovers: A Reassessment: Comment." American Economic Review 95(1):461-64.

von Hippel, Eric. 1986. "Lead Users: A Source of Novel Product Concepts." Management Science 32(7):791-805.

Howell, Sabrina T. 2017. "Financing Innovation: Evidence from R\&D Grants." American Economic Review 107(4):1136-64.

Jaffe, Adam B., Michael S. Fogarty, and Bruce A. Banks. 1998. "Evidence from Patents and Patent Citations on the Impact of NASA and Other Federal Labs on Commercial Innovation.” The Journal of Industrial Economics 46(2):183-205.

Jaffe, Adam B., and Josh Lerner. 2001. "Reinventing Public R\&D: Patent Policy and the Commercialization of National Laboratory Technologies." The RAND Journal of Economics 32(1):167-98.

Jaffe, Adam B., and Manuel Trajtenberg. 1996. "Flows of Knowledge from Universities and Federal Laboratories: Modeling the Flow of Patent Citations over Time and across Institutional and Geographic Boundaries." Proceedings of the National Academy of Sciences 93(23):12671-77.

Jones, Benjamin F. 2010. "Age and Great Invention." The Review of Economics and Statistics 92(1):1-14.

Jones, Benjamin F., and Bruce A. Weinberg. 2011. "Age Dynamics in Scientific Creativity." Proceedings of the National Academy of Sciences 108(47):18910-14.

Lanahan, Lauren, Alexandra Graddy-Reed, and Maryann P. Feldman. 2016. "The Domino Effects of Federal Research Funding.” PLOS ONE 11(6):e0157325.

Li, Danielle, Pierre Azoulay, and Bhaven N. Sampat. 2017. "The Applied Value of Public Investments in Biomedical Research.” Science 356(6333):78-81.

Light, Paul C. 2017. The True Size of Government Tracking Washington's Blended Workforce, 1984-2015. The Volcker Alliance.

Mansfield, Edwin. 1995. "Academic Research Underlying Industrial Innovations: Sources, Characteristics, and Financing." The Review of Economics and Statistics 77(1):55-65. 
Mazzucato, Mariana. 2013. The Entrepreneurial State: Debunking Public vs. Private Sector Myths. London: Anthem Press.

Morrison, Pamela D., John H. Roberts, and Eric von Hippel. 2000. "Determinants of User Innovation and Innovation Sharing in a Local Market." Management Science 46(12):1513-27.

Morrison, Pamela D., John H. Roberts, and David F. Midgley. 2004. "The Nature of Lead Users and Measurement of Leading Edge Status." Research Policy 33(2):351-62.

Murray, Fiona, and Scott Stern. 2007. "Do Formal Intellectual Property Rights Hinder the Free Flow of Scientific Knowledge?: An Empirical Test of the Anti-Commons Hypothesis." Journal of Economic Behavior \& Organization 63(4):648-87.

Owen-Smith, Jason, and Walter W. Powell. 2001. "To Patent or Not: Faculty Decisions and Institutional Success at Technology Transfer." The Journal of Technology Transfer 26(12):99-114.

Rai, Arti K., and Bhaven N. Sampat. 2012. "Accountability in Patenting of Federally Funded Research.” Nature Biotechnology 30(10):953-56.

Rein, Lisa. 2014. “As Federal Government Evolves, Its Clerical Workers Edge toward Extinction." Washington Post, January 14.

Singer, Peter. 2014. Federally Supported Innovations. Washington, D.C.: MIT Washington Office.

Trajtenberg, Manuel. 1990. "A Penny for Your Quotes: Patent Citations and the Value of Innovations.” The RAND Journal of Economics 21(1):172-87.

Trajtenberg, Manuel, Rebecca Henderson, and Adam Jaffe. 1997. "University Versus Corporate Patents: A Window On The Basicness Of Invention." Economics of Innovation and New Technology 5(1):19-50.

Vries, Hanna de, Victor Bekkers, and Lars Tummers. 2016. "Innovation in the Public Sector: A Systematic Review and Future Research Agenda." Public Administration 94(1):146-66.

Zhang, Congshan, and John M. de Figueiredo. 2018. "Are Recessions Good for Government Hires? The Effect of Unemployment on Public Sector Human Capital." Economics Letters 170:1-5.

Zucker, Lynne G., and Michael R. Darby. 1996. "Star Scientists and Institutional Transformation: Patterns of Invention and Innovation in the Formation of the Biotechnology Industry." Proceedings of the National Academy of Sciences 93(23):12709-16. 
Table 1: Innovation in American Government Award Examples

Source: Ash Center at the Harvard Kennedy School; Winners of the Innovation in American Government Award, 1995-1999 (see: https://www.innovations.harvard.edu)

\begin{tabular}{|c|c|c|}
\hline Agency & Program Title & Year \\
\hline $\begin{array}{l}\text { Department of } \\
\text { Defense }\end{array}$ & National Defense on the Offense & 1995 \\
\hline U.S. Air Force & Ozone Depleting Chemical Elimination & 1995 \\
\hline $\begin{array}{l}\text { Bureau of } \\
\text { Reclamation }\end{array}$ & Reinvention of the Bureau of Reclamation & 1995 \\
\hline $\begin{array}{c}\text { Pension Benefit } \\
\text { Guaranty Corporation }\end{array}$ & Early Warning Program & 1995 \\
\hline $\begin{array}{c}\text { Immigration and } \\
\text { Naturalization Service }\end{array}$ & Operation Jobs & 1995 \\
\hline $\begin{array}{c}\text { Federal Emergency } \\
\text { Management Agency }\end{array}$ & $\begin{array}{l}\text { Consequence Assessment Tool Set and } \\
\text { Operations Concept }\end{array}$ & 1996 \\
\hline $\begin{array}{l}\text { Housing and Urban } \\
\text { Development }\end{array}$ & $\begin{array}{l}\text { Consolidated Planning/Community } \\
\text { Connections }\end{array}$ & 1996 \\
\hline Department of Labor & No Sweat: Eradicating Sweatshops & 1996 \\
\hline $\begin{array}{l}\text { Food and Drug } \\
\text { Administration }\end{array}$ & Reform of the U.S. Drug Approval Process & 1997 \\
\hline $\begin{array}{l}\text { Internal Revenue } \\
\text { Service }\end{array}$ & TeleFile & 1997 \\
\hline $\begin{array}{l}\text { Department of } \\
\text { Defense }\end{array}$ & Best Manufacturing Practices Program & 1998 \\
\hline $\begin{array}{l}\text { Consumer Product } \\
\text { Safety Commission }\end{array}$ & Fast-Track Product Recall Program & 1998 \\
\hline U.S. Forest Service & $\begin{array}{l}\text { Northern New Mexico Collaborative } \\
\text { Stewardship }\end{array}$ & 1998 \\
\hline $\begin{array}{c}\text { Centers for Disease } \\
\text { Control } \\
\end{array}$ & PulseNet & 1999 \\
\hline $\begin{array}{l}\text { Housing and Urban } \\
\text { Development }\end{array}$ & Continuum of Care & 1999 \\
\hline
\end{tabular}


Table 2: OLS Regression Models of Patent Originality, Generality, and Citations

\begin{tabular}{cccc} 
& Patent Originality & Patent Generality & Patent Citations \\
\hline Assignee Type & & & \\
Government & $0.0484^{* * * *}$ & $0.0462^{* * *}$ & $-3.3760^{* * *}$ \\
& $(0.0025)$ & $(0.0022)$ & $(0.1211)$ \\
University & $0.0551^{* * *}$ & $0.0576^{* * *}$ & $1.8102^{* * *}$ \\
& $(0.0018)$ & $(0.0020)$ & $(0.1106)$ \\
All Others & Reference & Reference & Reference \\
& Category & Category & Category \\
Grant Year FE & Yes & Yes & Yes \\
CPC Group FE & Yes & Yes & Yes \\
\hline Constant & $0.4502^{* * *}$ & $0.4911^{* * * *}$ & $16.0662^{* * * *}$ \\
& $(0.0220)$ & $(0.0212)$ & $(0.5415)$ \\
\hline Observations & $1,733,166$ & $1,460,715$ & $4,646,540$ \\
$R^{2}$ & 0.0956 & 0.1166 & 0.1216 \\
\hline
\end{tabular}

Notes: Robust standard errors in parentheses.

**** $p<.001$ 
Figure 1: The GS Grade Distribution, FY1988 vs. FY2011

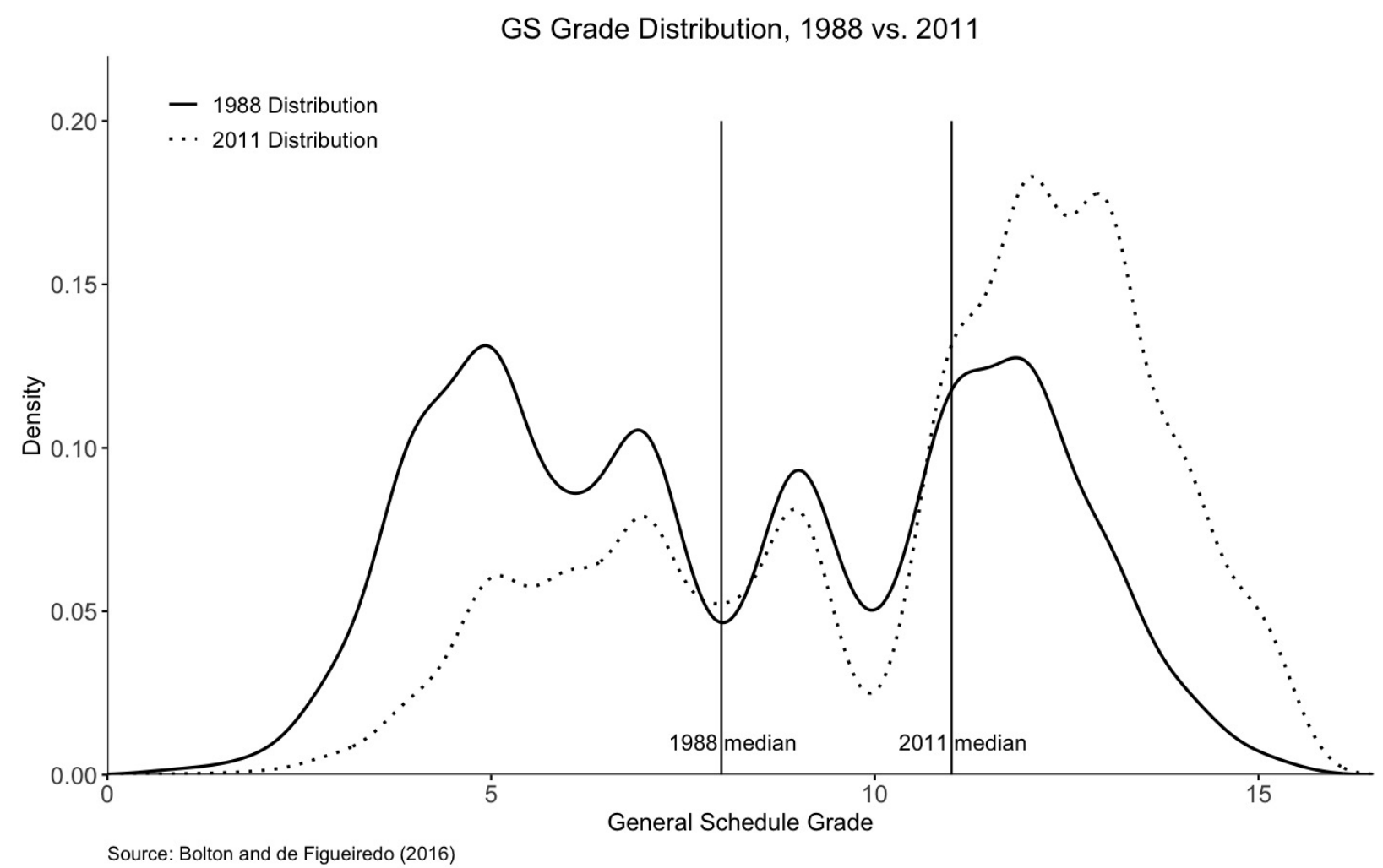


Figure 2: Federal Personnel Occupation Categories, FY1988-2011

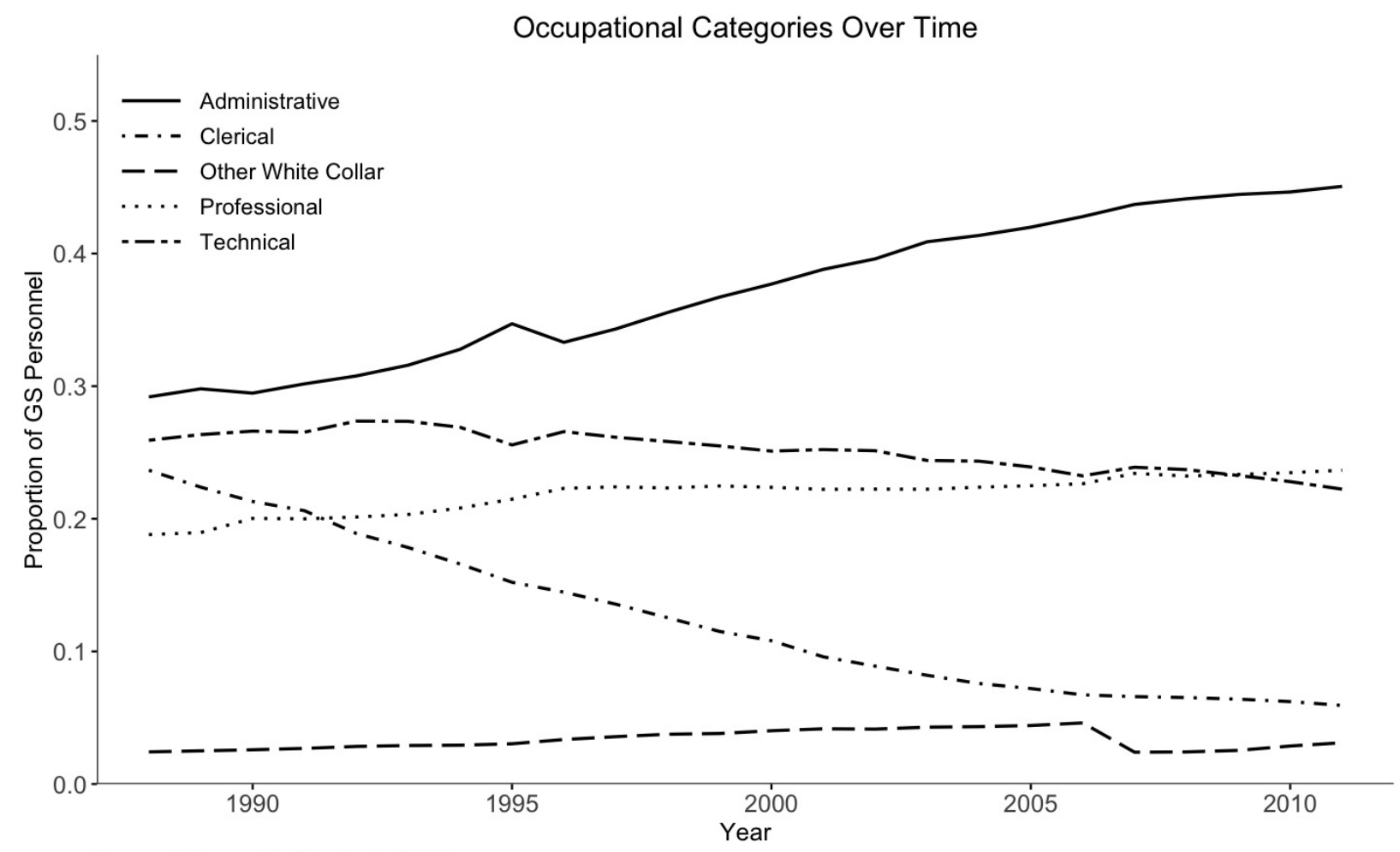

Source: Bolton and de Figueiredo (2016) 
Figure 3a: Distribution of Federal Spending Across Agencies

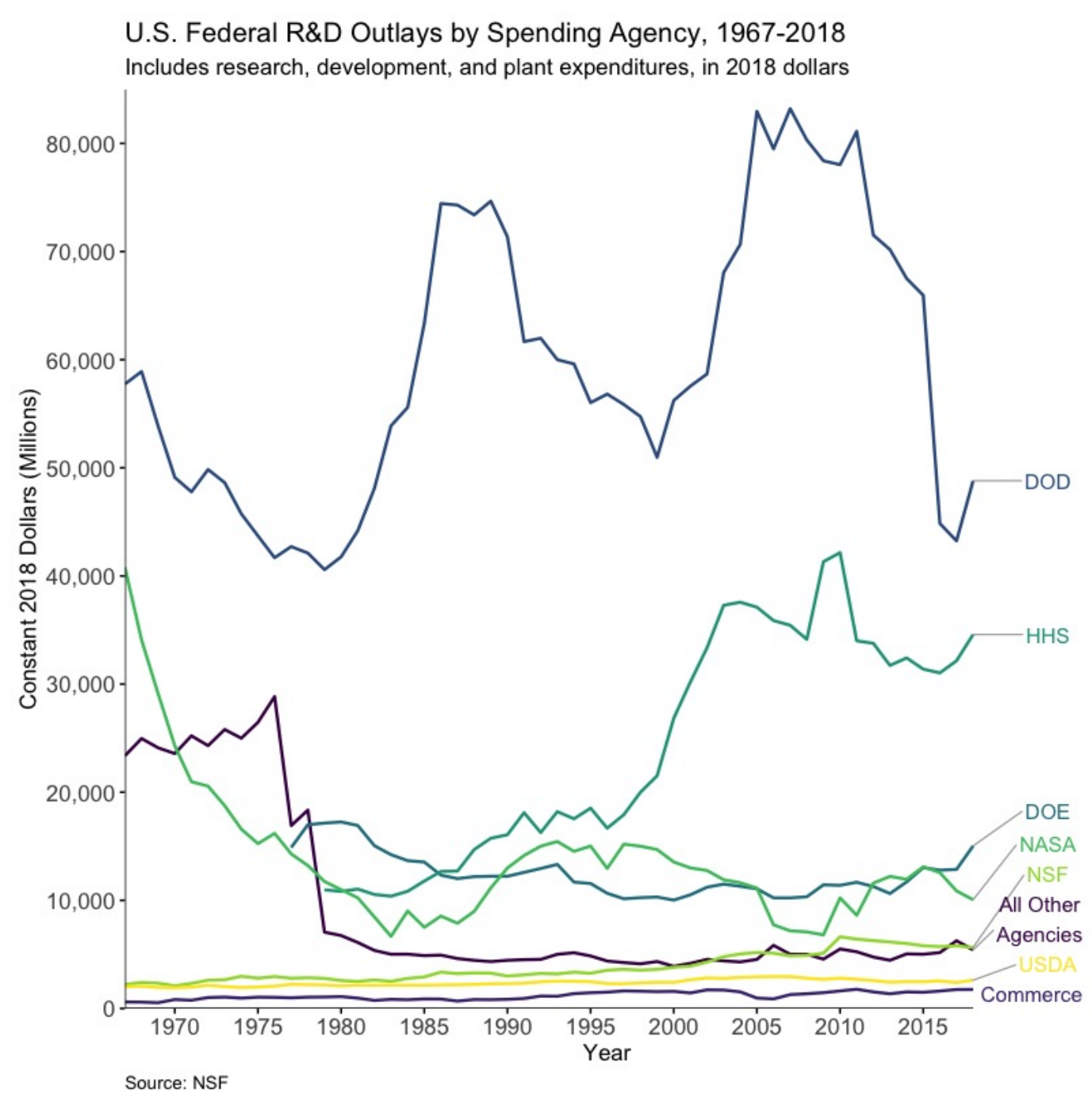


Figure 3b: Performers of Federally Funded R\&D

U.S. Federal R\&D Obligations by Type of Performer, 1967-2018

Includes research, development, and plant obligations, in 2018 dollars

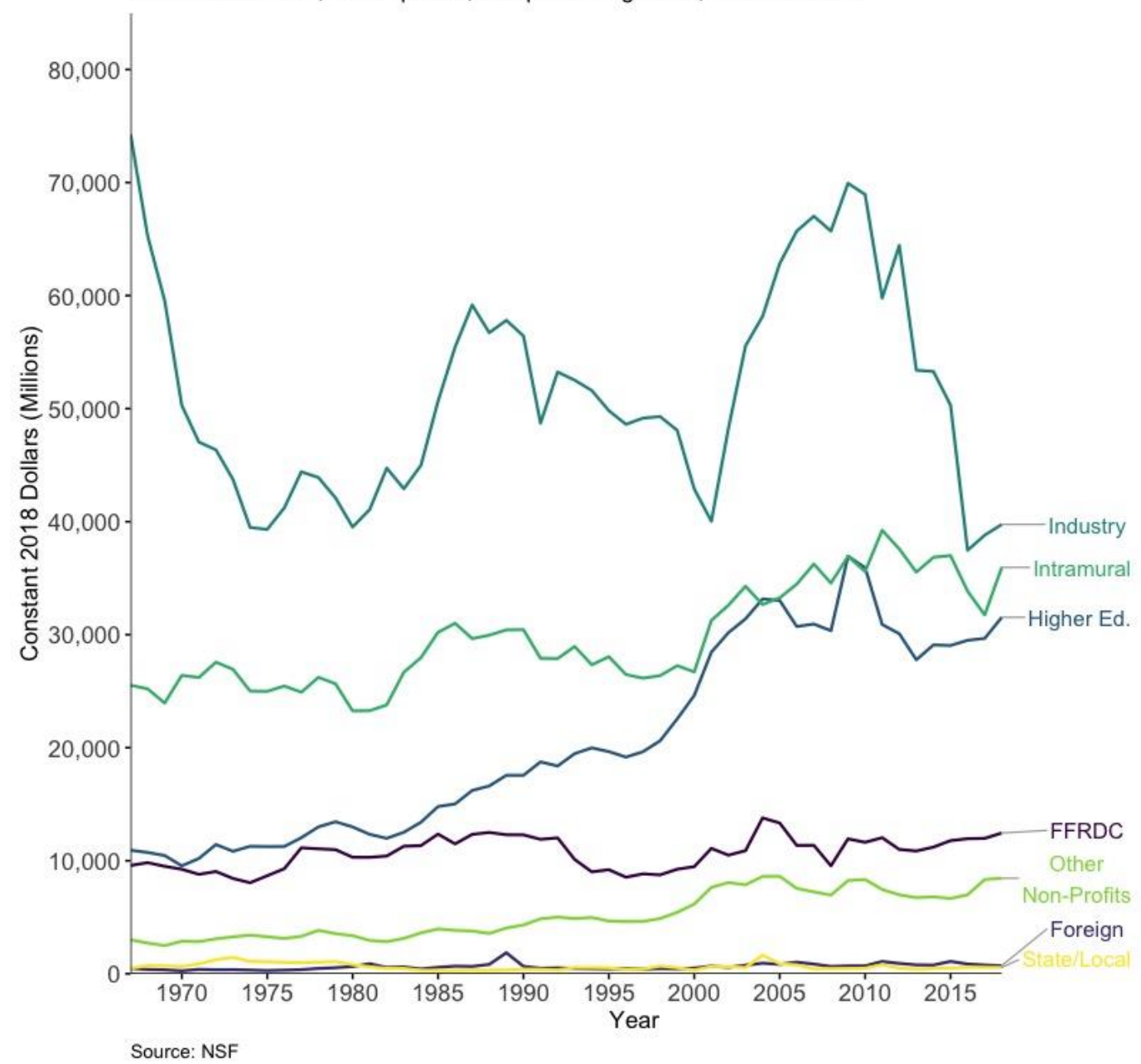


Figure 4a: Total Federal Scientific Employment, 1980-2014

Total Scientific Employment in DOD and Non-DOD Agencies, 1980-2014

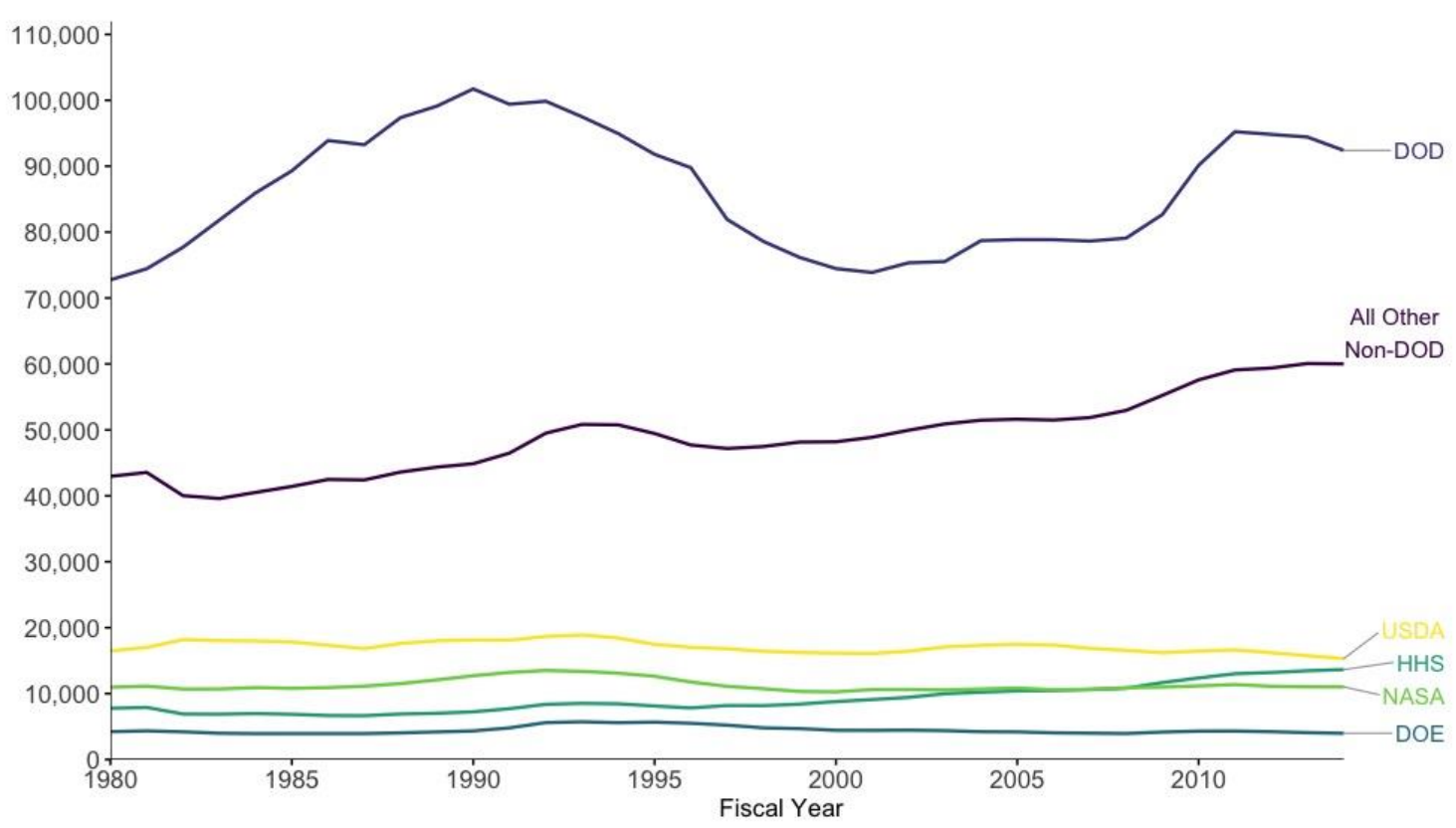

Figure 4b: Percent of Employees in Scientific Occupations, 1980-2014

Percentage of Agency Workforce in Scientific Positions, 1980-2014

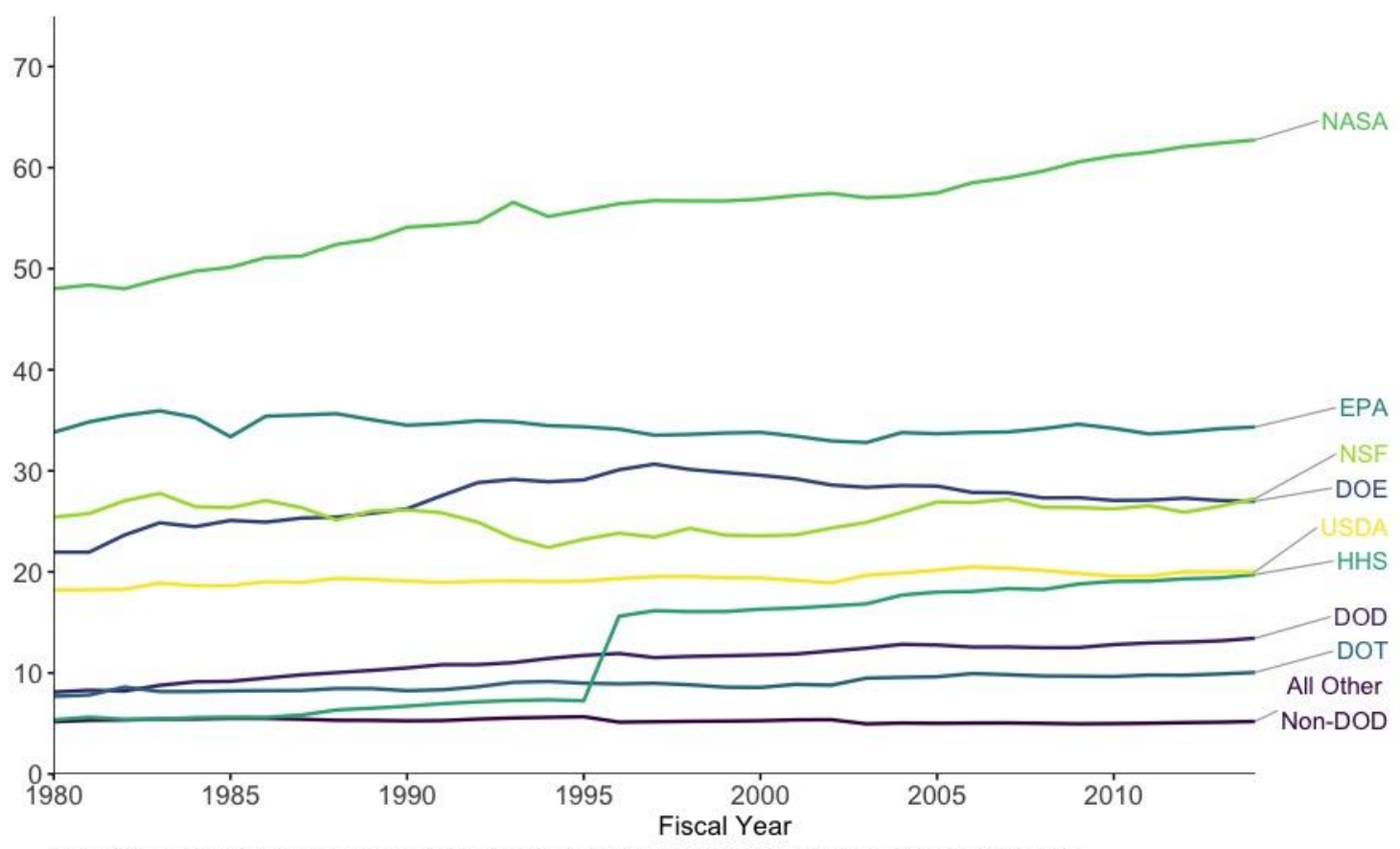

Note: Discontinuity in HHS line due to Social Security Administration being re-organized outside HHS in 1995. 
Figure 5a: Scientists by R\&D Functional Classification, 1988-2011

Federal Personnel by R\&D Functional Classifications and DOD Affiliation, 1989-2011

R\&D-Focused Positions

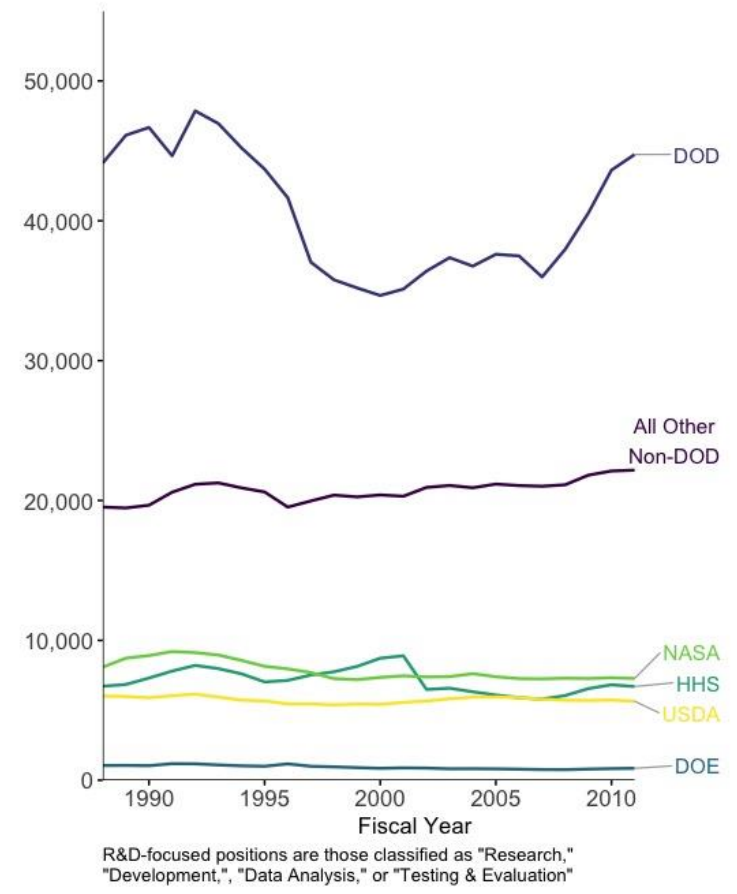

R\&D-Adjacent Positions

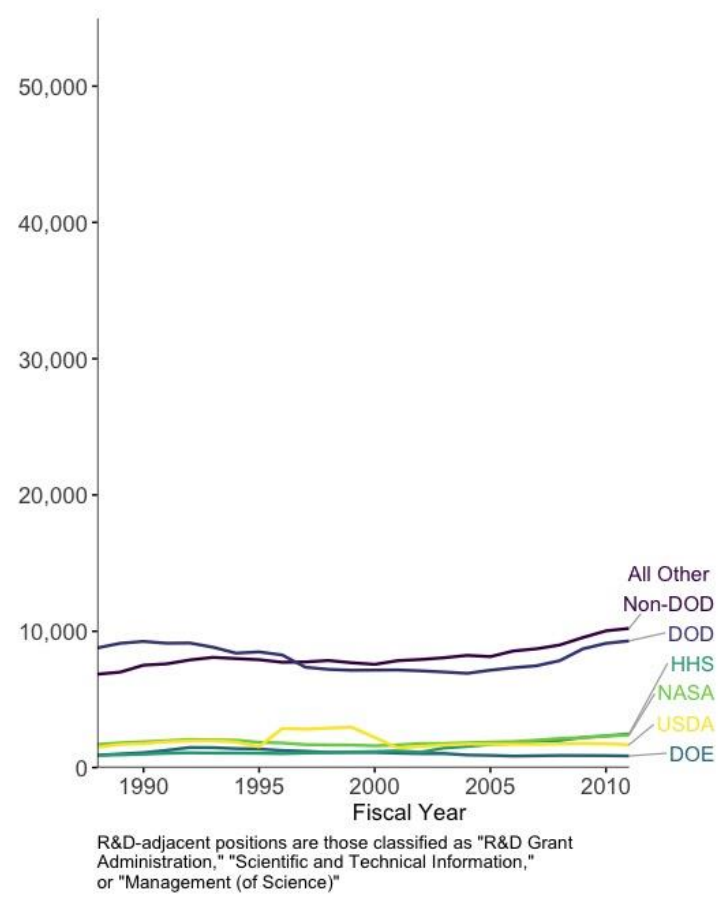

Figure 5b: Percent of Scientists by R\&D Functional Classification, 1988-2011 Percent of Scientists by R\&D Functional Classifications, 1989-2011

R\&D-Focused Positions

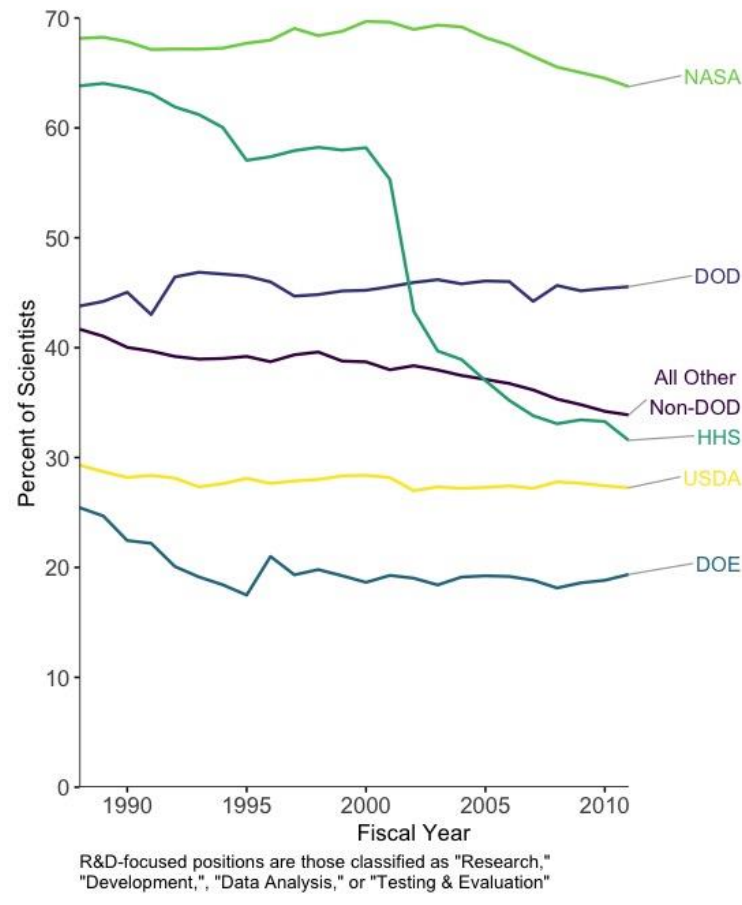

R\&D-Adjacent Positions

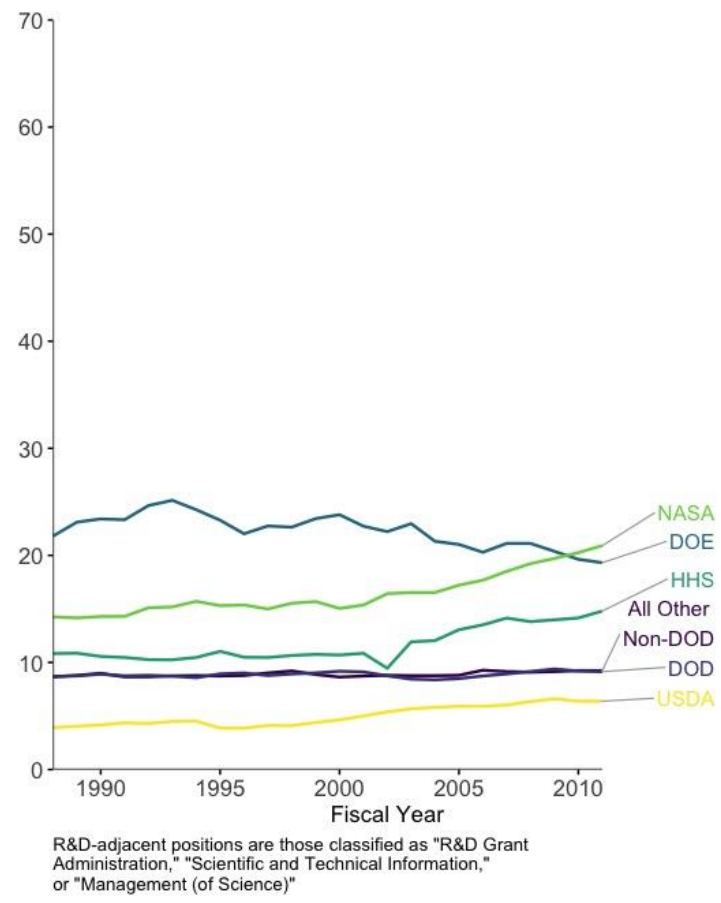


Figure 6: Federal Scientists by Scientific Area, 1980-2014

Federal Personnel by Area of Science as Percent of Annual Total, 1980-2014

DOD Personnel
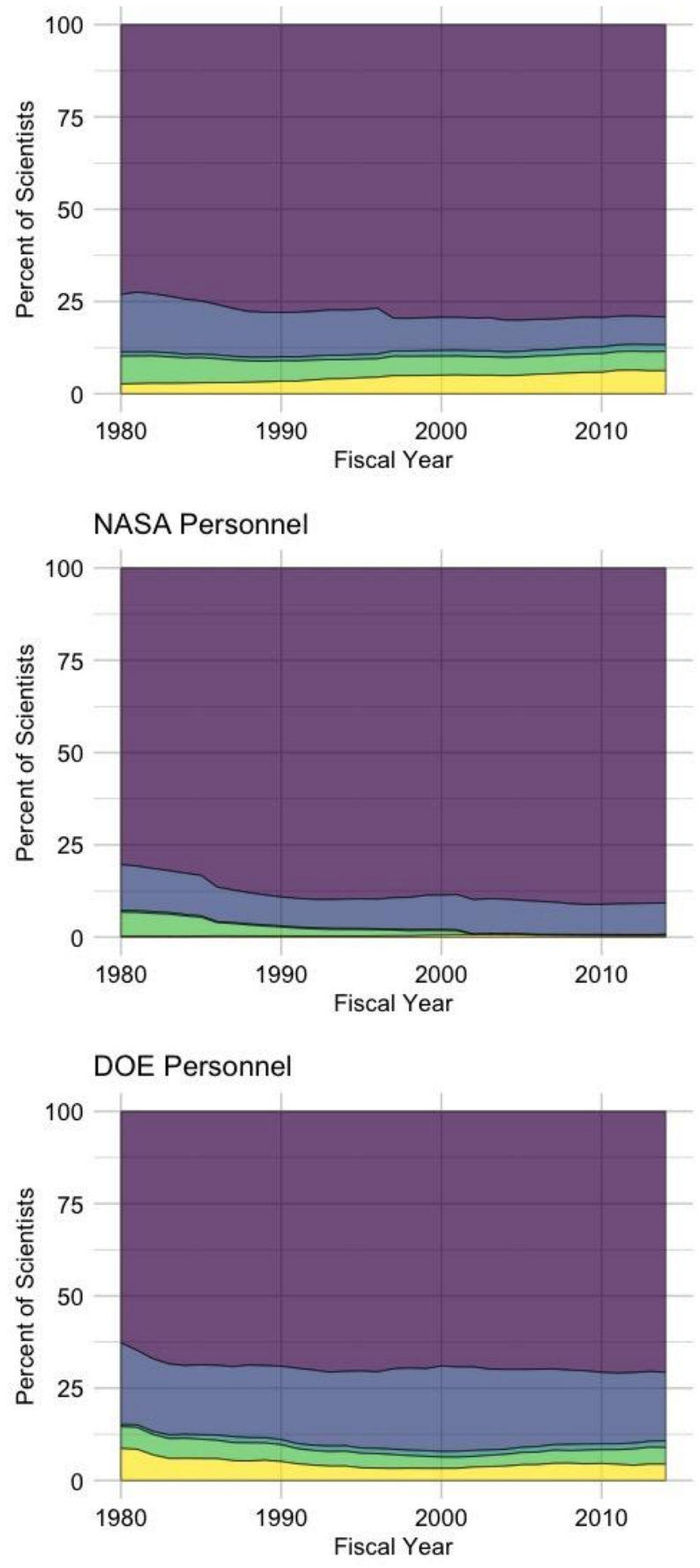

Area of Science
Engineering
Physical Sciences
Non-DOD/NASA/HHS/DOE/USDA Personnel
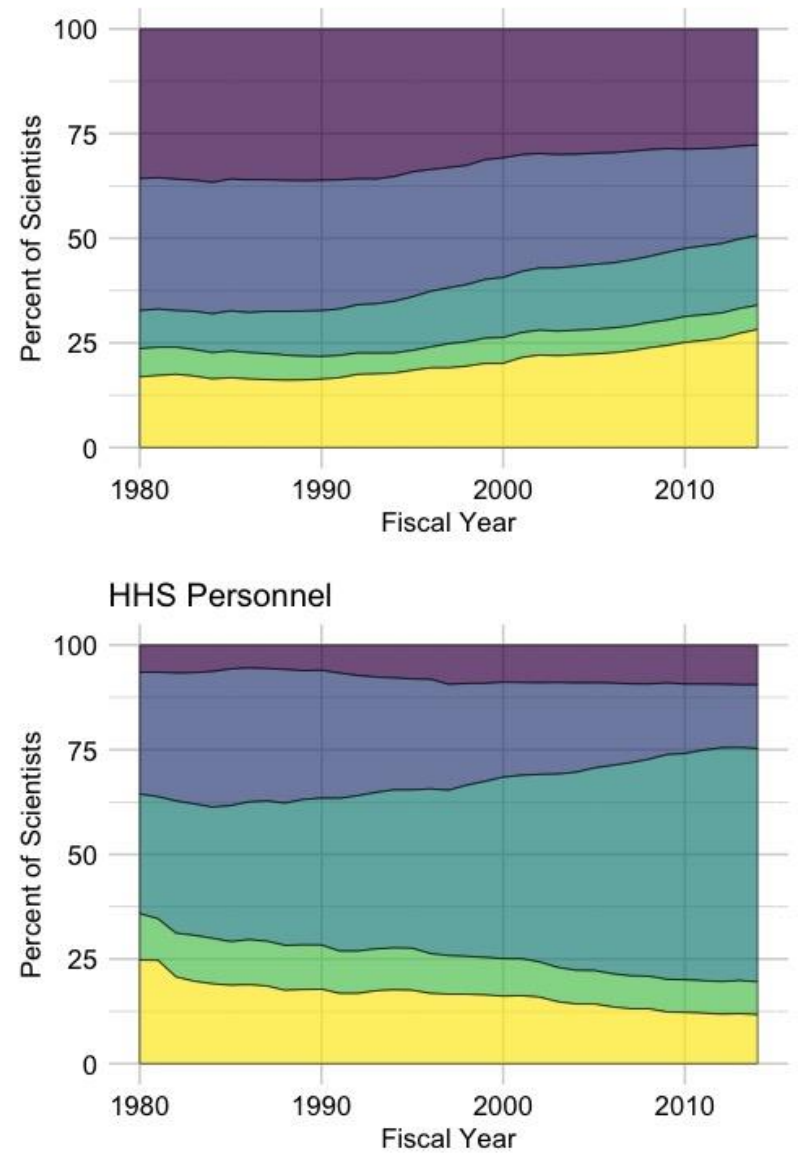

USDA Personnel

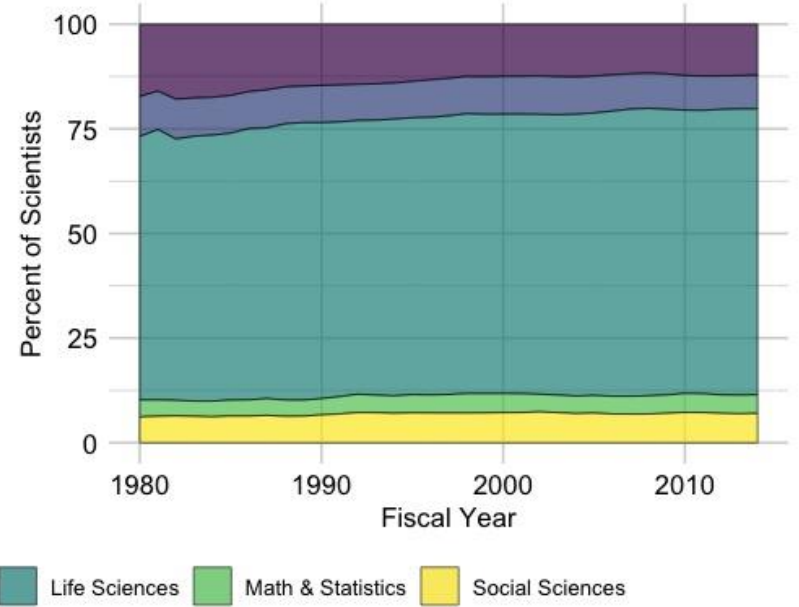


Figure 7: U.S. Patents by Government Assignment and Interest, 1975-2013

Annual US Patents with Government Affiliation, 1975-2013

Data on government affiliation type from PatentsView.org

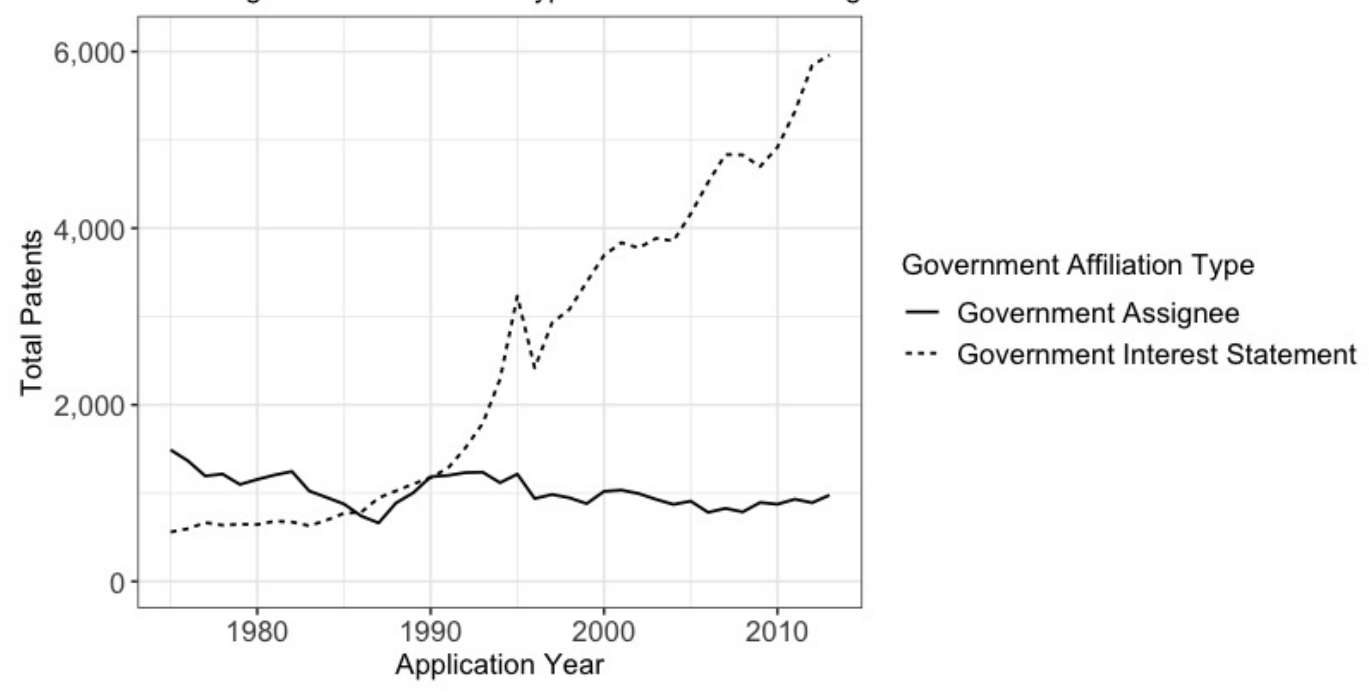


Figure 8a: Total Patents Assigned to Government Agencies, 1975-2013

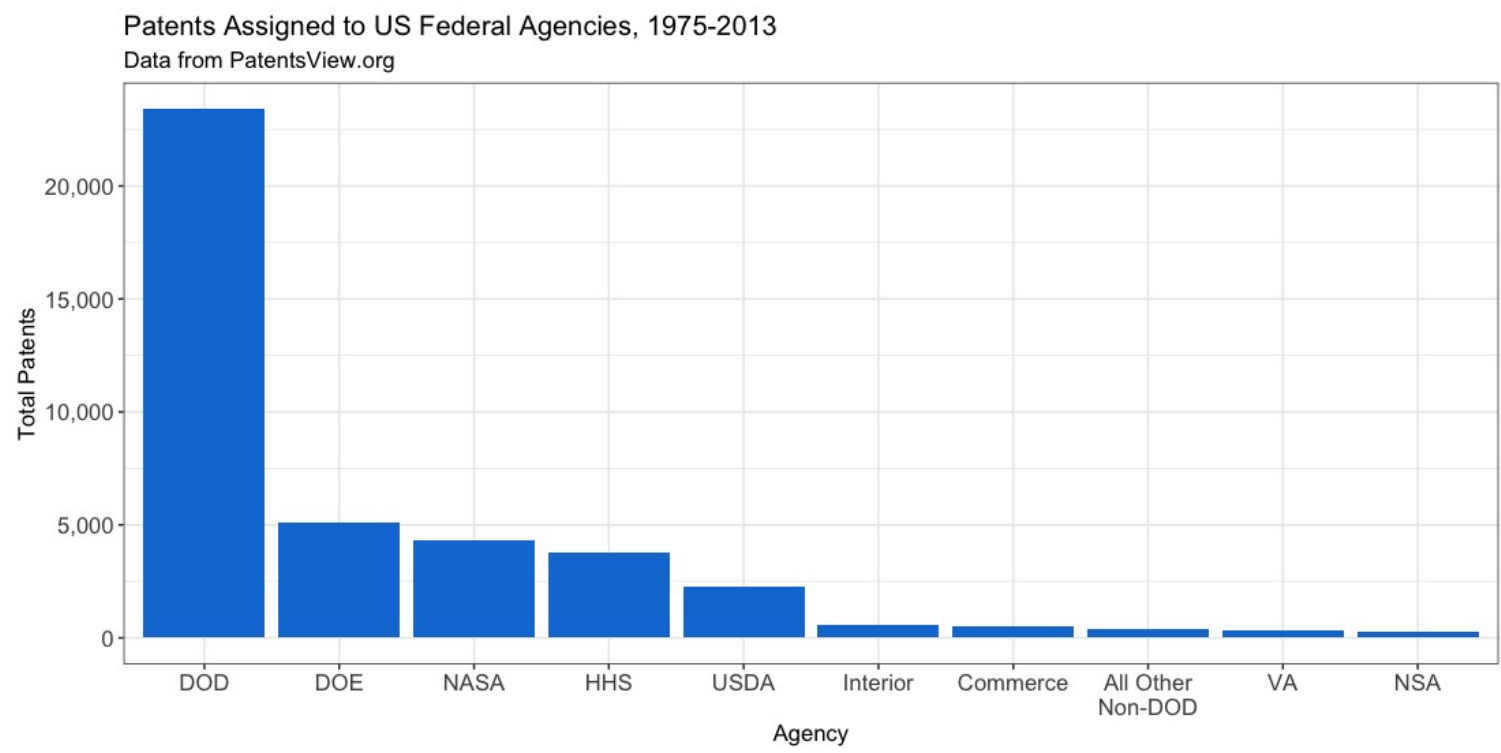

Figure 8b: Total Patents with Government Interest Statement by Agency, 1975-2013

Patents with Government Interest Statements by Federal Agency, 1975-2013

Data from PatentsView.org

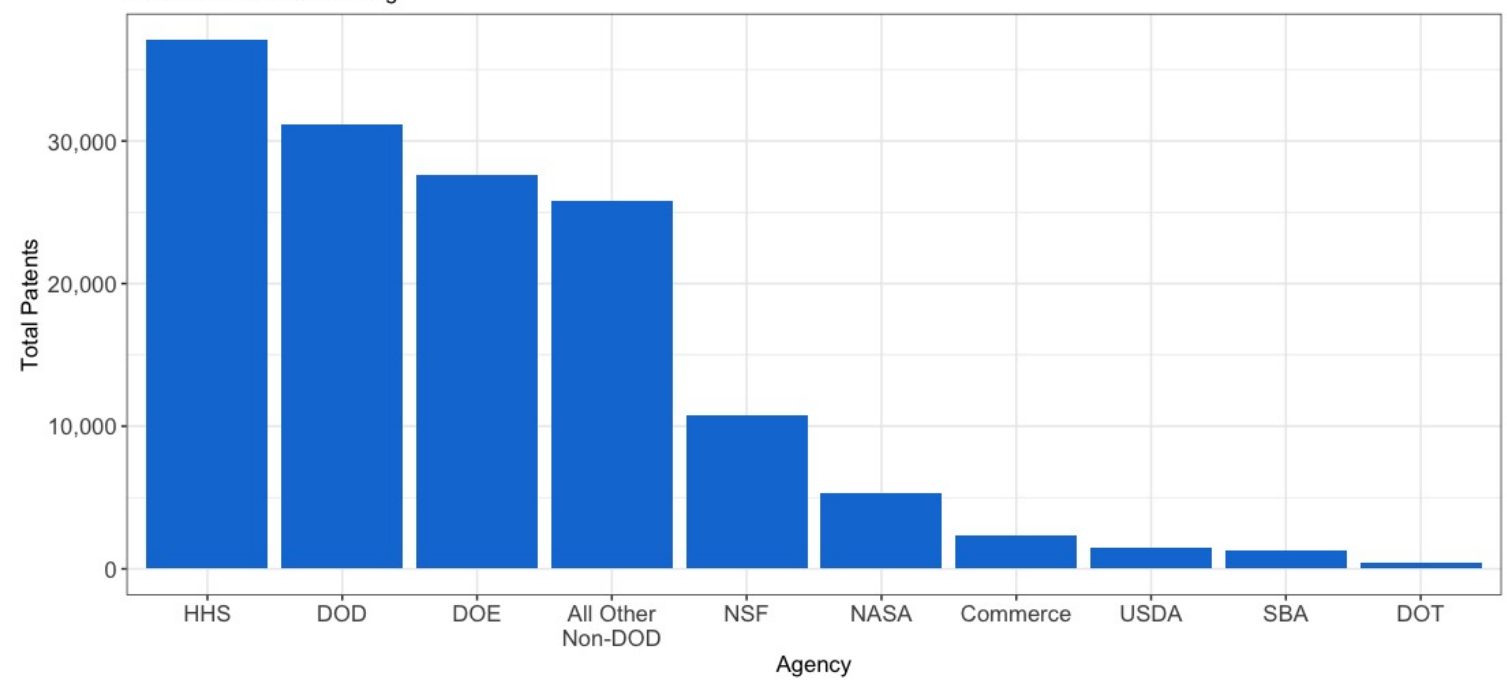


Figure 9: Number of Patents Granted in Government's Top Six CPC Subsections, 1975-2013

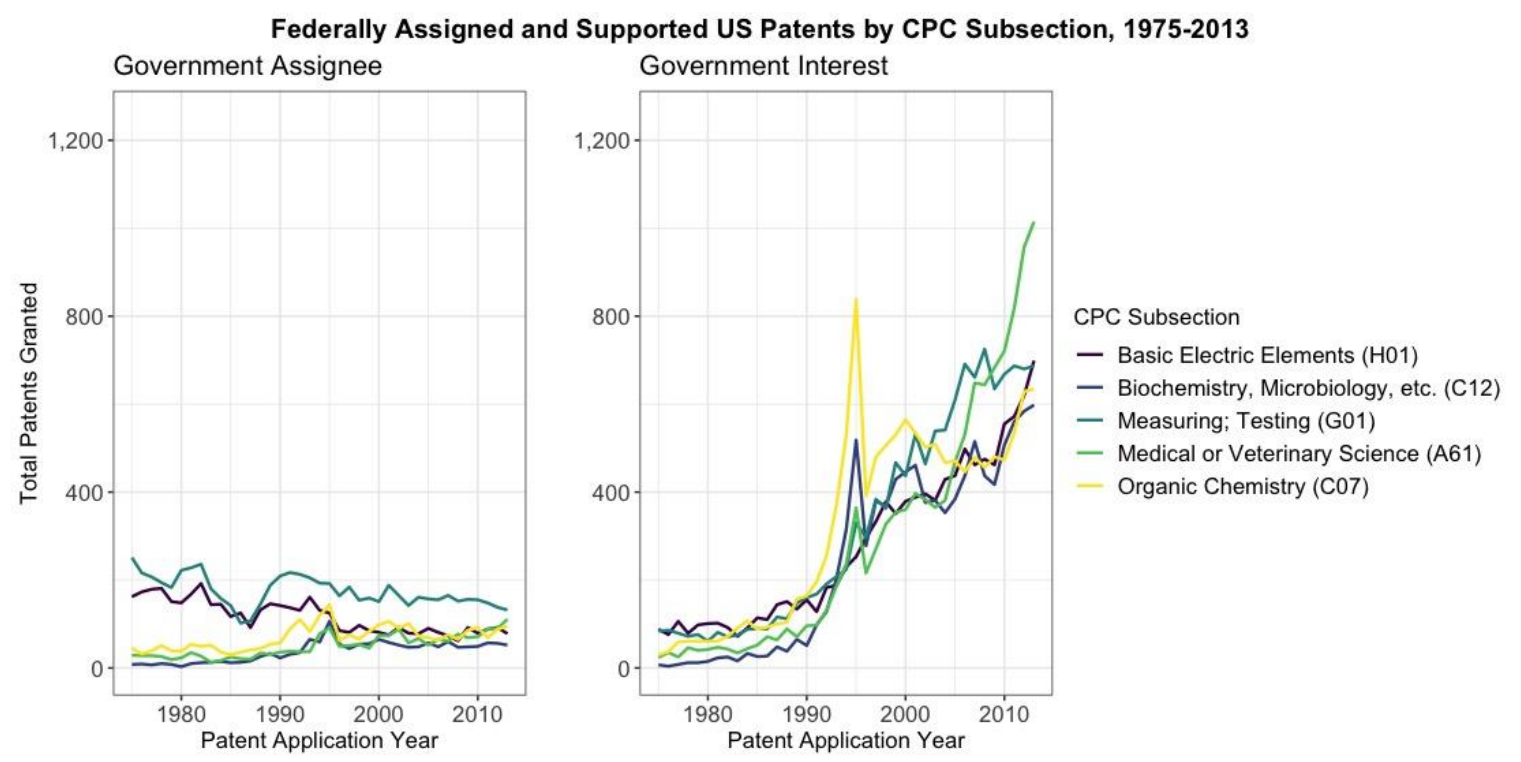


Figure 10: Top CPC Patent Groups by Government Assignment, 1975-2013

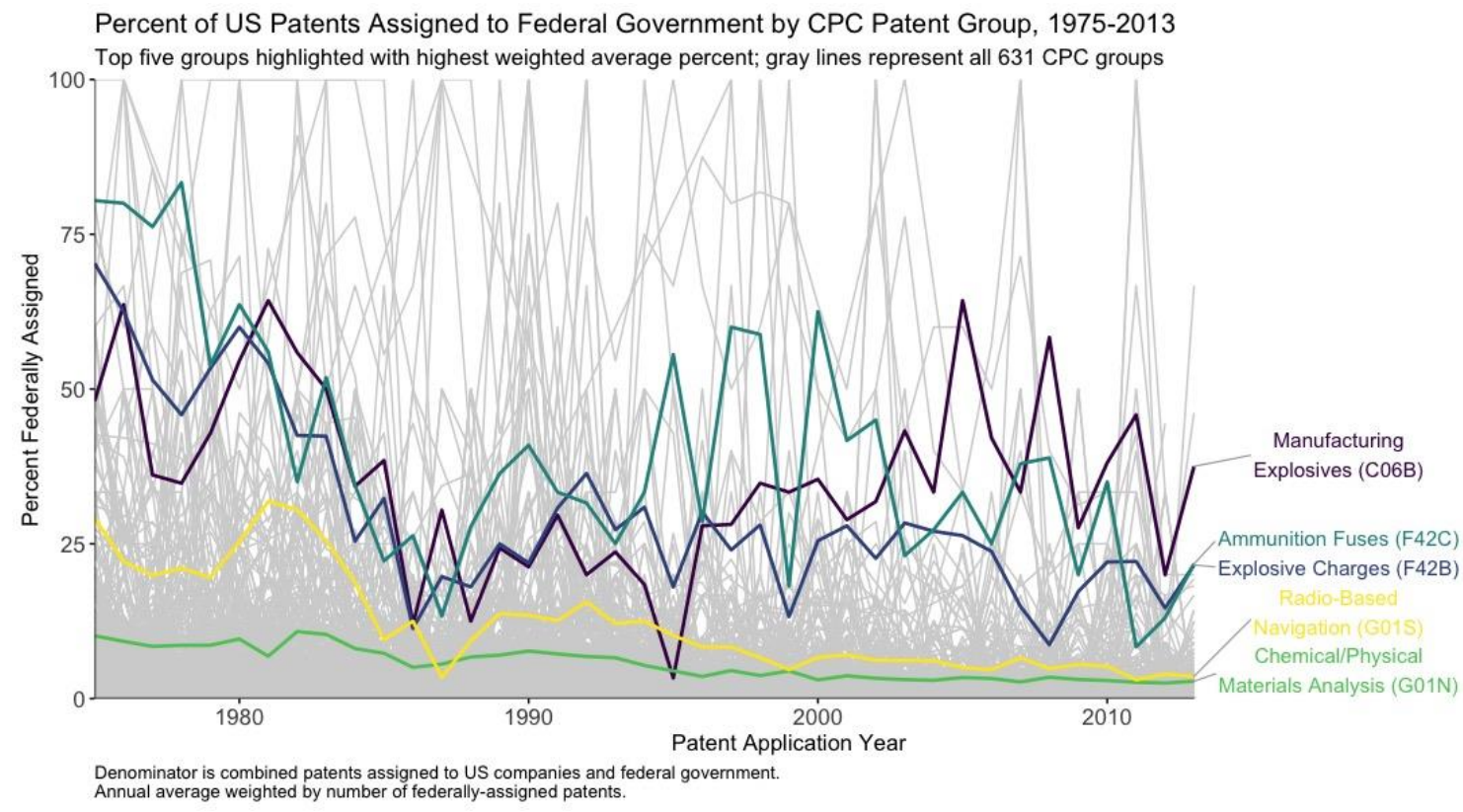




\section{Figure 11a}

Average Patent Originality in "Measuring; Testing (G01)" Patents, 1980-2003 Patent citation records from NBER Patent Data Project.

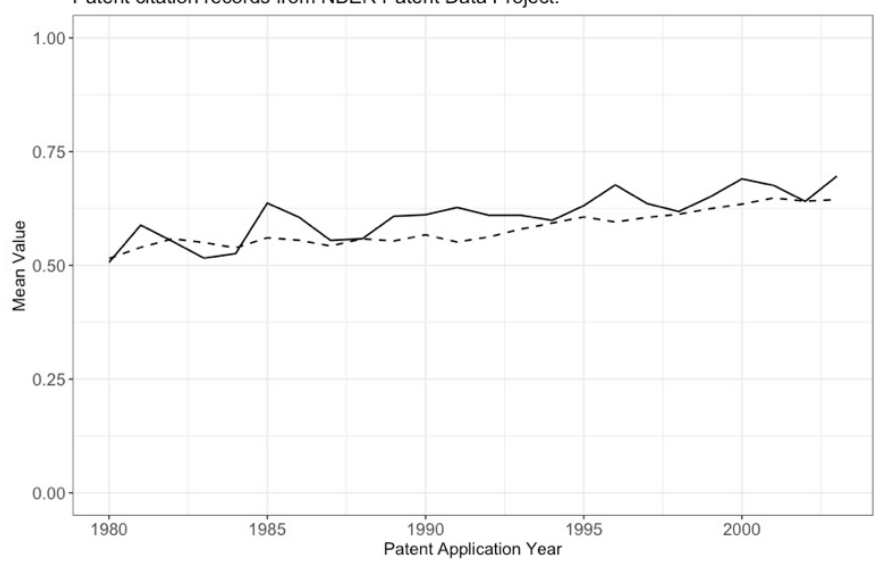

Figure $11 b$

Average Patent Generality in "Measuring; Testing (G01)" Patents, 1975-1999 Patent citation records from NBER Patent Data Project.

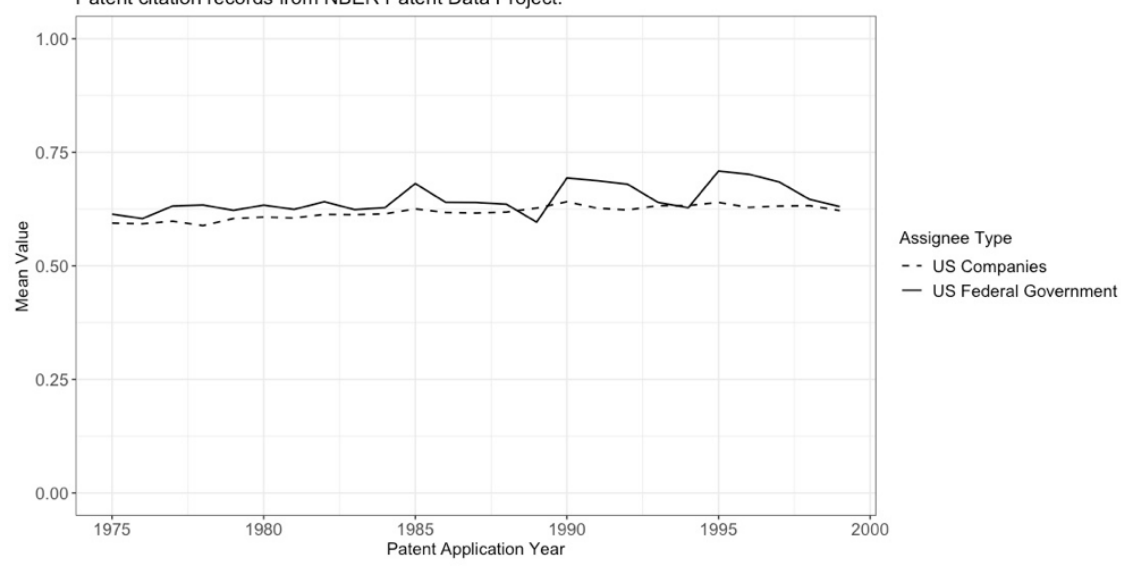

Figure 11c

Average Patent Citations in "Measuring; Testing (G01)" Patents, 1975-2003 Patent citation records from NBER Patent Data Project.

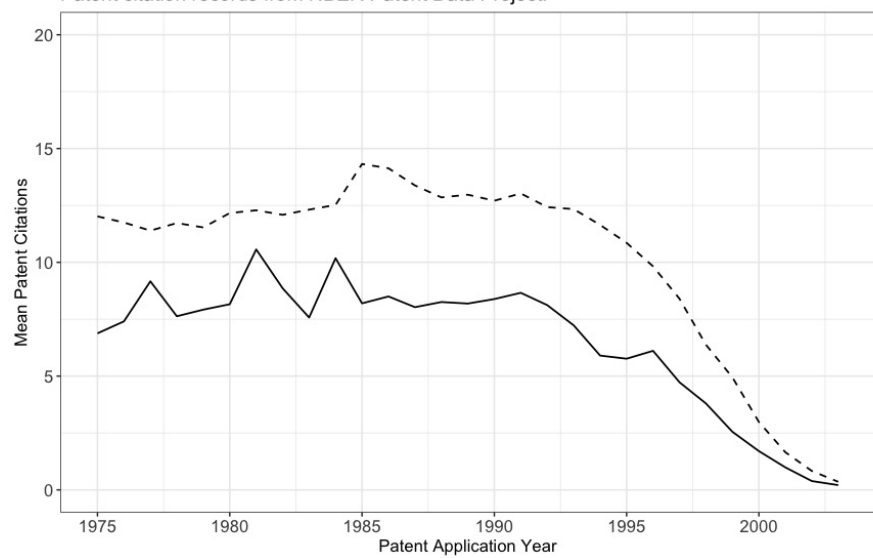

Assignee Type

- - US Companies

- US Federal Government 
Figure 12: State-Level Intramural R\&D Spending, 2006-2018

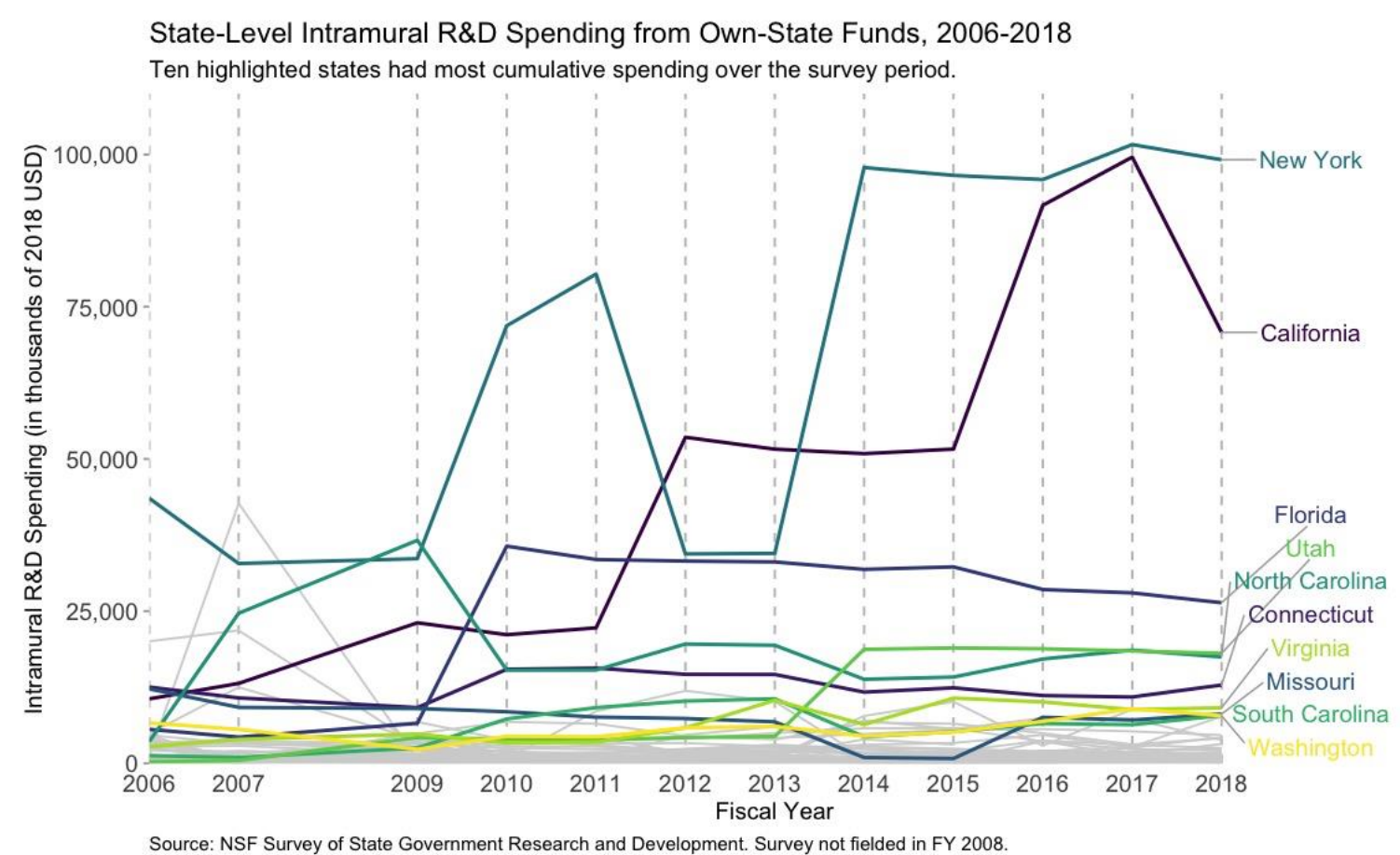

